\title{
Deciphering the preservation of fossil insects: a case study from the Crato Member, Early Cretaceous of Brazil
}

Gabriel Ladeira Osés Corresp., ${ }^{1}$, Setembrino Petri ${ }^{2}$, Bruno Becker Kerber ${ }^{3}$, Guilherme Raffaeli Romero ${ }^{4}$, Marcia de Almeida Rizzutto ${ }^{5}$, Fabio Rodrigues ${ }^{6}$, Douglas Galante ${ }^{7}$, Tiago Fiorini da Silva ${ }^{5}$, Jessica F Curado ${ }^{8}$, Elidiane Cipriano Rangel ${ }^{9}$, Rafael Parra Ribeiro ${ }^{9}$, Mírian Liza Alves Fora Pacheco ${ }^{10}$

${ }^{1}$ Programa de Pós-graduação em Geoquímica e Geotectônica, Institute of Geosciences, Universidade de São Paulo, São Paulo, Brazil

2 Institute of Geosciences, Universidade de São Paulo, São Paulo, Brazil

3 Programa de Pós-Graduação em Ecologia e Recursos Naturais, Universidade Federal de São Carlos, São Carlos, São Paulo, Brazil

4 Institute of Geosciences, Universidade Federal do Pará, Belém, Brazil

5 Institute of Physics, Universidade de São Paulo, São Paulo, Brazil

${ }^{6}$ Department of Fundamental Chemistry / Institute of Chemistry, Universidade de São Paulo, São Paulo, Brazil

7 Brazilian Synchrotron Light Laboratory, Campinas, Brazil

8 Department of Physics, Centro Universitário FEl, São Bernardo do Campo, Brazil

9 Laboratory of Technological Plasmas, Universidade Estadual Paulista, Sorocaba, Brazil

${ }^{10}$ Department of Biology, Universidade Federal de São Carlos, Sorocaba, Brazil

Corresponding Author: Gabriel Ladeira Osés

Email address: gabriel.ladeiraoses@gmail.com

Exceptionally well-preserved three-dimensional insects with fine details and even labile tissues are ubiquitous in the Crato Member Konservat Lagerstätte (northeastern Brazil). Here we investigate the preservational pathways which yielded such specimens. We employed high resolution techniques (EDXRF, SR-SXS, SEM, EDS, micro Raman, and PIXE) to understand their fossilisation on mineralogical and geochemical grounds. Pseudomorphs of framboidal pyrite, the dominant fossil microfabric, display size variation when comparing cuticle with inner areas or soft tissues, which we interpret as the result of the balance between ion diffusion rates and nucleation rates of pyrite through the originally decaying carcasses. Furthermore, the mineral fabrics are associated with structures that can be the remains of extracellular polymeric substances (EPS). Geochemical data also point to a concentration of $\mathrm{Fe}, \mathrm{Zn}$, and $\mathrm{Cu}$ in the fossils in comparison to the embedding rock. Therefore, we consider that biofilms of sulphate reducing bacteria (SRB) had a central role in insect decay and mineralisation. Therefore, we shed light on exceptional preservation of fossils by pyritisation in a Cretaceous limestone lacustrine palaeoenvironment. 
1 Deciphering the Preservation of Fossil Insects: a Case Study from the Crato Member, Early

3 Gabriel Ladeira Osés ${ }^{1}$, Setembrino Petri ${ }^{2}$, Bruno Becker Kerber ${ }^{3}$, Guilherme Raffaeli Romero ${ }^{4}$,

4 Márcia de Almeida Rizzutto 5 , Fabio Rodrigues ${ }^{6}$, Douglas Galante ${ }^{7}$, Tiago Fiorini da Silva ${ }^{5}$,

5 Jessica Curado ${ }^{8}$, Elidiane Cipriano Rangel ${ }^{9}$, Rafael Parra Ribeiro ${ }^{9}$, Mírian Liza Alves Forancelli

6 Pacheco $^{10}$

7 Programa de Pós-graduação em Geoquímica e Geotectônica, University of São Paulo, São

8 Paulo, São Paulo, Brazil

9 Institute of Geosciences, University of São Paulo, São Paulo, São Paulo, Brazil

10 3Programa de Pós-graduação em Ecologia e Recursos Naturais, Federal University of São Carlos,

11 São Carlos, São Paulo, Brazil

$12{ }^{4}$ Institute of Geosciences, Federal University of Pará, Belém, Pará, Brazil

13 Institute of Physics, University of São Paulo, São Paulo, São Paulo, Brazil

$14{ }^{6}$ Institute of Chemistry, University of São Paulo, São Paulo, São Paulo, Brazil

$15 \quad{ }^{7}$ Brazilian Synchrotron Light Laboratory, Campinas, São Paulo, Brazil

$16{ }^{8}$ Department of Physics, FEI Academic Centre, São Bernardo do Campo, São Paulo, Brazil

$17{ }^{9}$ Laboratory of Technological Plasmas, São Paulo State University, Sorocaba, São Paulo, Brazil

$18{ }^{10}$ Department of Biology, Federal University of São Carlos, Sorocaba, São Paulo, Brazil

19 Corresponding author:

20 Gabriel Osés

21 Rua do Lago, 562, Cidade Universitária, São Paulo, SP, 05508-080, Brazil 
22 Email address: gabriel.oses@usp.br

\section{Abstract}

24 Exceptionally well-preserved three-dimensional insects with fine details and even labile tissues

25 are ubiquitous in the Crato Member Konservat Lagerstätte (northeastern Brazil). Here we

26 investigate the preservational pathways which yielded such specimens. We employed high

27 resolution techniques (EDXRF, SR-SXS, SEM, EDS, micro Raman, and PIXE) to understand 
28 their fossilisation on mineralogical and geochemical grounds. Pseudomorphs of framboidal

29 pyrite, the dominant fossil microfabric, display size variation when comparing cuticle with inner

30 areas or soft tissues, which we interpret as the result of the balance between ion diffusion rates

31 and nucleation rates of pyrite through the originally decaying carcasses. Furthermore, the mineral

32 fabrics are associated with structures that can be the remains of extracellular polymeric

33 substances (EPS). Geochemical data also point to a concentration of $\mathrm{Fe}, \mathrm{Zn}$, and $\mathrm{Cu}$ in the fossils

34 in comparison to the embedding rock. Therefore, we consider that biofilms of sulphate reducing

35 bacteria $(\mathrm{SRB})$ had a central role in insect decay and mineralisation. Therefore, we shed light on

36 exceptional preservation of fossils by pyritisation in a Cretaceous limestone lacustrine

37 palaeoenvironment.

\section{Introduction}

Exceptionally preserved biotas have been recorded since the Precambrian (e.g. Chen et al., 2014). They comprise taphonomic windows (Konservat-Lagerstätten of Seilacher, Reif \& Westphal, 1985), which provide essential evidence for understanding major issues regarding evolution and palaeoecology of ancient ecosystems (e.g. Raff et al., 2008). In fact, organisms with low potential of preservation are very promising as taphonomic windows since once they retain fine morphological aspects, this implies in high taxonomic fidelity, representative of an ancient biological community (Briggs \& McMahon, 2016).The high preservational fidelity of insects from the Crato Member (Santana Formation, northeastern Brazil) defines it as a taphonomic window for an Early Cretaceous ecosystem (Soares et al., 2013). Due to this kind of unique record, we know that the evolutionary history of the insects was characterised by major radiation and extinction events in the Cretaceous (Nicholson et al., 2015), when the diversification of social insects (Jarzembowski and Ross, 1996; Engel et al., 2007) and the 
51 radiation of flowering plants (Lidgard \& Crane, 1988) took place. The latter has impacted insect

52 evolution thereafter (Jarzembowski and Ross, 1996; Labandeira, 2014).

53 Within the palaeolacustrine setting of the Crato Member, several insect groups display

54 exceptional preservation of non-biomineralised tissues on a micron-scale as well as gross

55 morphological features (Delgado et al., 2014; Barling et al., 2015). Martínez-Delclòs, Briggs \&

56 Peñalver (2004) have pointed out the common association of insect soft-tissue preservation with

57 fine-grained laminated carbonates, which is indeed the case of the Crato Member. Whilst

58 previous studies have considered the preservation of these organisms (Heimhofer \& Martill,

59 2007; Menon \& Martill, 2007; Delgado et al., 2014; Barling et al., 2015), microtextural and

60 geochemical analyses have not been performed, nor has a detailed taphonomic model been

61 proposed. Based on imaging, geochemical, and mineralogical analyses, this paper presents data

62 that supports the central role of microorganisms in the fossilisation of the Crato Member insects.

63 We propose a preservational pathway able to predict interconnections between geobiological and

64 taphonomic processes operating in the exceptional preservation of these insects, which have

65 yielded 3D replicas with mineralised internal soft tissues.

\section{Geological Setting}

67 The fossil insects used in this study are from the Crato Member (Santana Formation,

68 Araripe Basin) located in northeastern Brazil (Fig. 1). It is a continental rift basin, bounded by

69 NE and WNW faults (Assine, 2007), formed during the opening of the South Atlantic Ocean

70 (Brito-Neves, 1990; Assine, 2007).

The base of the Araripe Basin is comprised by the Cariri Formation, proposed by Beurlen

72 (1962) (Late Ordovician/Early Devonian) (Assine, 2007). Four supersequences are recognised in

73 the Araripe Basin (following Assine, 2007): 1- Pre-rift Supersequence: siliciclastic fluvial- 
74 lacustrine sediments from both the Brejo Santo and Missão Velha formations, dated to the Late

75 Jurassic by ostracodes and palynomorphs (Coimbra, Arai \& Carreño, 2002); 2- Rift

76 Supersequence: deltaic, fluvial and lacustrine siliciclastic sediments from the Abaiara Formation,

77 attributed to the Early Cretaceous based mainly on ostracode biozonation (Coimbra, Arai \&

78 Carreño, 2002); 3- Post-rift Supersequence: Barbalha Formation, with two fluvial

79 (siliciclasts)/lacustrine (pelites and carbonates) cycles and the Santana Formation, both units

80 occurring within the Araripe Group and Aptian-Albian in age (Coimbra, Arai \& Carreño, 2002).

81 The lower succession of the Barbalha Formation comprises the "Camadas Batateira", which

82 represent the first evidence of an anoxic lacustrine cycle. In the Araripina Formation, heterolitic

83 facies of alluvial fan plains of the Mesoalbian occur. This unit is overlaid by fluvial sediments of

84 the Exu Formation (Araripe Group), located in the top of the Araripe Basin, whose age is

85 uncertain due to the absence of microfossils (Coimbra, Arai \& Carreño, 2002), although its

86 stratigraphic position suggests an Albian-Cenomanian age (Coimbra, Arai \& Carreño, 2002;

87 Assine, 2007).

88 The Santana Formation is divided in two members. The Crato Member, the most basal

unit, outcrops only in the east portion of the Araripe Basin (Viana \& Neumann, 2000). Its Late

90 Aptian age is based mainly on palynomorphs (Coimbra, Arai \& Carreño, 2002). This unit consists

91 of carbonates, forming intermittent banks, more than 20 meters thick (Assine, 2007). These

92 carbonates are divided into six levels, each one with basal clay-carbonate rhythmites overlaid by

93 micritic laminated limestones, where the fossil insects from this study occur (Viana \& Neumann,

94 2000). These lithologies were deposited in a lacustrine palaeoenvironment. The carbonate levels

95 are interbedded with shales (occasionally rich in organic matter), sandstones, and siltstones

96 (Viana \& Neumann, 2000).

97 In the top of the Crato Member, supratidal gypsum layers and shales, known as the

98 “Camadas Ipubi” occur (Assine, 2007). Transgressive events led to the deposition of siliciclastic 
99 marine sediments, with shales with carbonatic fossiliferous nodules from the Romualdo Member

100 (Kellner, 2002), the Santana Formation top stratigraphic unit (Assine, 2007). Both “Camadas

101 Ipubi" and Romualdo Member comprise the Late Aptian-Early Albian interval, defined by

102 palynozones (Coimbra, Arai \& Carreño, 2002). Above the Romualdo Member, a level with

103 marine shell beds occurs, which is covered by regressive freshwater facies (Beurlen, 1971), in the

104 upper part of the Santana Formation.

\section{Materials and Methods}

106 The specimens analysed ("GP/1E") are deposited in the Scientific Palaeontological

107 Collection of the Institute of Geosciences of the University of São Paulo (Brazil). No permits

108 were required for the described study since it was performed after specimens had been deposited

109 in the above mentioned scientific collection. The results herein presented comprise the analyses

110 of the following samples: GP/1E 7105, GP/1E 8440, GP/1E 8397, GP/1E 8827, GP/1E 6820,

111 GP/1E 10368, and GP/1E 9137.

112 The analyses were made with complementary paleometrical techniques (Delgado et al.,

113 2014) on weathered samples, in order to validate the results of several techniques.

114 Samples were initially observed and photographed in a Zeiss Stemi 2000-C

115 stereomicroscope coupled to a Zeiss AxioCam ICc3 camera. The image acquisition was made in 116 the software AxionVision 4.8.

117 Micro morphological analyses of the fossil insects were conducted by scanning electron 118 microscopy (SEM) in a JEOL JSM-6010 LA microscope and also in a FEI Quanta 650 FEG 119 microscope, both coupled to an energy dispersive X-ray spectroscopy (EDS) equipment. In the 120 former microscope, an X-ray Dry SD Hyper (EX-94410T1L11) detector with resolution of 129 to $121133 \mathrm{eV}$ for the $\mathrm{Mn} \mathrm{K} \alpha$ line at $3000 \mathrm{cps}$ was used. To avoid surface charging during SEM 
122 inspections samples were coated with a thin layer of gold-palladium using a DESK-V HP Cold

$123 \mathrm{Etch} /$ Sputter system. The micrographs were then taken using the secondary electron detector of

124 the microscopes (except one micrograph, which was taken using the backscattered electron

125 detector of the JEOL JSM-6010 LA microscope). All spectroscopic analyses were performed on

126 three main regions of the samples: inside the carcasses, on the cuticle, and on the surrounding

127 rock matrix. EDS point and mapping spectra were employed to highlight qualitative elemental

128 heterogeneities among these three regions. The results obtained with EDS were carefully

129 analysed and interpreted since EDS point analysis may lack spatial representativeness and EDS

130 mapping is a qualitative approach, which may be affected by sample topographic irregularities.

131 Energy dispersive X-ray fluorescence (EDXRF) analyses were performed for rapid

132 elemental characterisation of heavier elements, previously to EDS in order to select samples to

133 this latter technique. The portable EDXRF equipment consisted of a mini Amptek X-ray tube of

134 Ag anode and a Silicon Drift Detector (SDD - X-ray semiconductor detector) of 125 eV FWHM

135 for the $5.9 \mathrm{keV}$ line of $\mathrm{Mn}$. The measurements were carried out with $30 \mathrm{kV}$ voltage and $5 \mu \mathrm{A}$ of

136 tube current and with an excitation/detection time of $100 \mathrm{~s}$.

137 The quantitative detection of phosphorus in the samples was performed in vacuum, at the

138 soft X-ray spectroscopy (SXS) beamline of the Brazilian Synchrotron Light Laboratory (Abbate

139 et al., 1999), following the work of Leri et al. (2006).

140 The elemental mapping of a whole sample was made by the application of particle

141 induced X-ray emission (PIXE). The analysis was performed in the external beam setup of the

1421.7 MV-tandem accelerator of the University of São Paulo. A 2.4 MeV energy proton beam (1

$143 \mathrm{~mm}$ in diameter) was used at the sample surface to induce the emission of characteristic X-rays,

144 detected by an AMPTEK XR-100CR (450 $\mu \mathrm{m}$ thickness, $4.6 \mathrm{~mm}^{2}$ area, 0.5 mil Be-window, and

$145165 \mathrm{eV}$ energy-resolution at $5.9 \mathrm{keV}$, and additional X-ray absorber of $300 \mu \mathrm{m}$ to avoid high

146 counting rates). The sample was positioned in front of the external beam setup by a robotic 
147 sample holder that sequentially moved the sample to cover the fossil area by a matrix of analysed

148 spots (0.7 mm steps in both directions). In each point, the sample holder stands during the

149 detector acquisition time, which in the case of this study was $15 \mathrm{~s}$ with a beam current of $10 \mathrm{nA}$,

150 and saves an X-ray spectra for each point. The maps were created using the peak area

151 (background removed) and the position of each measured point tracked by the robotic sample 152 holder.

153 The mineralogical composition of both fossils and laminated limestone was analysed by

154 Raman spectroscopy in a confocal micro Raman inVia Renishaw equipment, coupled to a laser of

$155785 \mathrm{~nm}$ wavelength and $300 \mathrm{~mW}$ power and a laser of $633 \mathrm{~nm}$ wavelength and $17 \mathrm{~mW}$ power, 156 and a CCD detector. The Raman spectra were analysed in the software Origin ${ }^{\circledR} 8$.

\section{Results and Discussion}

\section{Microtextural Characterisation of the Fossils}

SEM analysis revealed that fossil exoskeletons (Fig. 2) are preserved by sub-spherical to spherical closely-packed grains, with diameters mainly in the range of 5 to $10 \mu \mathrm{m}$ (Fig. 3A), which are formed by anhedral to euhedral nanocrystals (Fig. 3B-D). The outer cuticle surface retains fine morphological details (Fig. 3A; Barling et al., 2015), built by the close-packing of these grains (Fig. 3A-D; Grimes et al., 2002). The cuticle is also replaced by polygonal lamellar sometimes porous structures likely filled with nanocrystals similar to the ones forming the sub-/spherical grains and with an anhedral microcrystalline mineral phase, with less than $1 \mu \mathrm{m}$ 166 (Fig. 3D).

The inner portion of the fossils (Fig. 2) is filled with sub-spherical to spherical generally loosely-packed grains of approximately $1 \mu \mathrm{m}$ in diameter, formed by nanocrystals (Fig. 3E and F). These grains sometimes have smoothed corroded surfaces and are partially disintegrated or covered by a fuzzy mineral phase (Fig. 3E; as showed by Barling et al., 2015 in Fig. 13E). 
171 Cuticle-replacing grains have dissolution cavities formerly occupied by crystals, which left empty

172 templates after oxidation (Fig. 3B and C; similar to Fig. 3B and 3D of MacLean et al., 2008).

173 Taking together, such evidence reinforces oxidation.

174 In some parts of both cuticle and internal cavities, individual grains are embedded in a

175 smooth matrix, forming clusters that vary in size and shape and are connected by "weblike"

176 structures (Fig. 3F).

\section{Geochemical Analyses}

Elemental analyses revealed that iron is more concentrated in fossils than in rock matrix,

179 while calcium and strontium are more concentrated in rock (Figs. 4-6; Fig. S1). The preferential

distribution of these elements is in accordance with the presence of iron compounds replacing the

fossils and the calcitic composition of the rock matrix (Barling et al., 2015). Zinc, copper, and

lead appear in a higher concentration in the fossils than in the laminated limestone (Figs. 5, 7,

Fig. S1). Lead and zinc may be attributed, respectively, to galena and sphalerite (Heimhofer \&

Martill, 2007). Concentrations of copper in fossils may point to the original precipitation of

sulphides along with pyrite, galena and sphalerite, reflecting reducing conditions (Heimhofer \&

Martill, 2007).

The low abundance of potassium, aluminium, silicon (Figs. 5, 6), plus oxygen in the

samples can be attributed to an aluminium silicate, probably k-feldspar, which occurs in the

laminated limestones (Heimhofer et al., 2010), or even to clay minerals formed after feldspar

weathering. PIXE mapping of elemental distribution revealed high concentrations of manganese

in the rock matrix (Fig. S1), indicating that disseminated pyrolusite does occur (Heimhofer \&

Martill, 2007).

We also showed higher concentrations of phosphorus in the fossils (50.000-60.000 ppm; 
196 between the concentration of calcium and phosphorus (Fig. 5) is consistent with the presence of

197 apatite in the samples. EDS elemental mapping of mineral fabrics and "weblike" structure (Fig.

198 7) revealed a marked preferential concentration of carbon in the latter.

199 Raman spectroscopy analysis indicated the presence of goethite or amorphous hematite in

200 fossils (Fig. 8; Faria \& Lopes, 2007). Therefore, iron and oxygen detected by other techniques

201 can be associated to these iron oxides/hydroxides, also documented by Barling et al. (2015) and

202 Grimaldi \& Maisey (1990).

\section{Preservation of Fossil Insects}

204 Microcrystals of framboidal pyrite or even of framboid pseudomorphs can be subhedral to

205 anhedral, as for example observed in fresh biofilms (MacLean et al., 2008) and replacing

206 Chengjiang (China) Cricocosmia worm (Gabbott et al., 2004). In samples here analysed, cuticle

207 sub-/spherical grain shape is sometimes obscured, possibly by grain collapse after weathering

208 (Barling et al., 2015), although Fig. 6A of Delgado et al. (2014) depicts grain shape. Moreover, it

209 is still possible to recognise often regular euhedral to subhedral microcrystal templates (Fig. 3

210 B,C) and anhedral microcrystals (Fig. 6A, inset, of Delgado et al., 2014). With such evidence in

211 mind, pyrite framboids can be actually defined as spherical to sub-spherical textures formed by

212 microcrystals often regular in shape and size (Canfield and Raiswell, 1991; Butler and Rickard,

213 2000). Therefore, we follow Delgado et al. (2014) in their interpretation that cuticle-replacing

214 microfabrics are composed of framboid pseudomorphs, while inner grains are herein considered

215 pseudomorphs after microframboidal pyrite (microframboid sensu Sawlowicz, 1993). Indeed,

216 microfabrics are mainly composed of iron and oxygen (Figs. 4 and 5), as also reported by

217 Delgado et al. (2014). Additionally, the polygonal lamellae structures associated with

218 pseudomorphs of pyrite crystals (Fig. 3D) could be interpreted as pyrite overgrowths around

219 originally precipitated pyrite framboids (e.g. Fig. 1D of Grimes et al., 2002). 
221 the lacustrine Jehol biota (China) insects, composed of framboids between 6-15 $\mu \mathrm{m}$ (Wang et al., 222 2012), but lacking microframboids. In Crato Member insects, it was possible to differentiate the

223 pyritic microtexture replacing cuticles from that infilling internal cavities or replacing soft tissues

224 (Delgado et al., 2014). This difference was not observed in the Jehol specimens. When cuticle is

225 preserved in these specimens, it is composed of isolated microcrystals (Wang et al., 2012), while

226 Crato Member exoskeletons are composed of coarse framboid pseudomorphs. Furthermore,

227 pyritised insects are also found in Cenozoic deposits, including those from (1) the Miocene

228 lacustrine bituminous beds of Rubielos de Mora (Spain), where pseudomorphs after framboidal 229 pyrite also fill the fossils (Peñalver et al., 1996), (2) the marine Eocene London Clay (England)

230 (Allison, 1988a), and (3) the Eocene Green River Formation (US), where fossils, putatively 231 preserved by iron oxides after pyrite, are hosted by lacustrine calcite mudstones (Anderson, 232 2012).

The geologic record of pyritised insects is less frequent in comparison to other types of mineral replacements, which are mainly restricted to the Cenozoic, and usually yield a higher degree of preservational fidelity than pyritisation. For instance, the Cenozoic insect record includes: silicification (Palmer, 1957); phosphatisation and calcification (Leakey, 1952; Duncan \& Briggs, 1996; Duncan et al., 1998; McCobb et al., 1998; Grimaldi \& Engel, 2005;

Schwermann et al., 2016); and specimens preserved within gypsum crystals (Schlüter et al., preserved respiratory system (tracheae), subcellular structures of muscles, digestive tract, reproductive organs, and glandular tissues (Voigt, 1938). the most accepted hypothesis for pyritisation in other Konservat Lagerstätte (e.g. Briggs et al., 
245 iron minerals (framboids and euhedral crystals) occurring in Chengjiang fossils have formed in

246 late diagenesis (cf. Forchielli et al., 2014). In order to both rule out the null hypothesis (i.e. late

247 diagenesis pyrite formation) and support the alternative hypothesis (i.e. early genesis hypothesis),

248 we present the following arguments:

249 1- We present evidence for 3D muscle fibre-a direct replication of soft-tissue micro

250 morphology with high fidelity of detail preserved, as shown below (Grimaldi, 2003 also depicts

251 muscle fibres; Barling et al., 2015 show preservation of genitalia)-replacement by framboidal

252 pyrite pseudomorphs, which would be quite unexpected in a late diagenetic or even weathering

253 mineral replacement, once, in fact, this kind of high and detailed preservation degree may be

254 obscured by later diagenesis;

255 2- We consider that it would be quite improbable to insect carcasses remain in 3D until

256 late-stage pyritisation took place, so it should have occurred early. Cuticle is made of large

257 merged pseudomorphs arranged in a way that has even preserved fine morphological details of

258 external cuticle, besides yielding 3D cuticle replicas. Furthermore, fossil tridimensionality also

259 leans on carcass infilling (Martínez-Delclòs, Briggs \& Peñalver, 2004) by microframboids, a

260 process that must have occurred early to prevent fossil compression (Peñalver et al., 1996);

2613 - We consider that the widespread fossil pyritisation is hardly explained in a moment

262 other than early diagenesis, when the most decay-prone organic matter is still available for SRB.

263 Indeed, mineralisation preferably stabilises labile substrates (Butterfield, 1995). Therefore, it is

264 difficult to understand (1) how pyrite would be concentrated in the carcasses, (2) the process

265 which has resulted in framboid size variation along carcasses (discussed below), and finally (3)

266 evidence for preserved extracellular polymeric substances (EPS) deeply associated with

267 microfabrics, if we favour the null hypothesis;

268 4- Several well-grounded controls for early diagenetic pyritisation were fulfilled in the

269 Crato palaeolake, such as scattered organic matter was low in the sediment (Neumann et al., 
270 2003), lack of bioturbation activity, and anoxic conditions (Heimhofer and Martill, 2007;

271 Schiffbauer et al., 2014 and references therein);

272 5- It is widely demonstrated and accepted that pyrite is precipitated by SRB during early

273 diagenesis, leading to organic matter mineralisation (Briggs et al., 1991; 1996; Grimes et al.,

274 2002; Briggs, 2003; Gabbott et al., 2004; Schiffbauer et al., 2014; Liu, 2016, among others).

275 Some of the filamentous structures associated with microfabrics could be interpreted as

276 soft-tissue decay amorphous products, as reported in a taphonomic experiment carried out by

277 Briggs and Kear (1993) using decaying shrimps, but they are different from soft tissues preserved

278 in the insects (Fig. 9). Moreover, several observations support that these structures, which seems

279 to have been originally flexible and pliable, are putative remaining fragmentary extracellular

280 polymeric substances (EPS) (Figs. 3F and 7; e.g. Fig. 10F in Toporski et al., 2002; Fig. 3A in

281 MacLean et al., 2008; Fig. 3F in Wang et al., 2012), and not EPS modern contamination,

282 confirming other current interpretations (e.g. Delgado et al, 2014):

283 1- These structures occur in fossils and were not found in the matrix (Toporski et

284 al.,2002), although EPS has been both found associated to calcite and microfossils in the host

285 rock and related to calcite genesis (Catto et al., 2016);

286 2- Figure 7A, for instance, shows that even after SEM vacuum the "weblike" structure has

287 not collapsed, as it would otherwise be expected since samples were not prepared to avoid the

288 collapse of recent hydrated structures (Défarge et al., 1996);

289 3- If these structures were modern contamination, one would expect the presence of

290 bacteria, however it does not happen. This observation is coherent with pyritisation being slower

291 than bacteria decay, thus hindering bacteria preservation. This would be possible by faster

292 mineralisation processes, such as phosphatisation (Briggs, 2003; Briggs et al., 2005);

293 4- The structures are structurally organised with mineral fabrics since putative EPS

294 involves them and microfabrics are embedded in a smooth matrix (Fig. 3F), as already 
295 mentioned, enabling grain cohesion, accordingly to the EPS definition of Characklis and Wilderer 296 (1989);

5- We actually expect the occurrence of EPS in the context of organomineralisation, such

298 as the precipitation of framboidal pyrite;

299 6- Finally, the association of high abundance of carbon to EPS (Fig. 7) is also well 300 documented in the Jehol biota fossil insects (Wang et al., 2012). Barling et al. (2015) suggested 301 that silica halos surrounding and partially covering Crato Member fossil insects might be 302 attributed to preserved bacterial biofilms, although they have not provided additional 303 morphological and/or geochemical evidence to support this interpretation. association with putative EPS, strengthens the hypothesis that biofilm-forming heterotrophic sulphate-reducing bacteria precipitated pyrite, accounting for the preservation of our fossils

Barling et al., 2015). Indeed, biofilms develop organic templates and suitable chemical microenvironmental conditions for the nucleation, growth and aggregation of pyrite crystals in framboids (MacLean et al., 2008). This explains mineral fabrics with empty cavities in the insects, originally filled with pyrite crystals, likely outlined by an organic template (Fig. 3B, C; very similar to Plate 14, Fig. 15 of Love, 1965 and to Fig. 3B and 3D of MacLean et al., 2008). Additionally, the relationship between decaying organic matter and pyrite growth (Brock, Parkes \& Briggs, 2006; Raff et al., 2008) has already been supported, for instance, by the presence of organic matter in framboids (MacLean et al., 2008), and the infilling of microfossils (Szczepanik,

316 Sawłowicz \& Bak, 2004) and of vertebrate bones (Peterson, Lenczewski \& Scherer, 2010) by

317 framboids. Actually, the same happens with the Crato Member insects, thus endorsing the 318 influence of SRB activity to mineralisation during carcass decay. Finally, biofilms create 319 geochemical gradients, controlling ion diffusion rates, directly affecting mineralisation (Briggs, 
320

321

323

324

325

2003; Peterson, Lenczewski \& Scherer, 2010; MacLean et al., 2008; Raff et al., 2008) and, hence promoting active organomineralisation (sensu Dupraz et al., 2008). This has already been evidenced by taphonomic experiments with decaying shrimp carcasses (Sagemann et al., 1999), which revealed that geochemical gradients are rapidly developed by oxygen and $\mathrm{pH}$ decrease, and sulphate reduction is triggered by anaerobic bacterial decay, leading to iron sulphide formation and soft-tissue preservation.

We propose that during early diagenesis, sulphate-reducing bacteria reduced sulphate $\left(\mathrm{SO}_{4}{ }^{2-}\right)$ to hydrogen sulphide $\left(\mathrm{H}_{2} \mathrm{~S}\right)$ (Heimhofer \& Martill, 2007) and, possibly, ferric iron $\left(\mathrm{Fe}^{3+}\right)$ to ferrous iron $\left(\mathrm{Fe}^{2+}\right)$ (Colemann et al., 1993; Gabbott et al., 2004; Popa, Kinkle \& Badescu, 2004; Heimhofer \& Martill, 2007) dissolved in pore water solutions, leading to pyrite formation, which is generally controlled by the amount of dissolved sulphate, reactive iron minerals and available decay-prone organic matter (Berner, 1984; Skei, 1988; Sawlowicz, 1993). This process led to exoskeleton mineralisation (e.g. Orr, Briggs, Kearns, 2008). Moreover, the diffusion of pore water solutions into and through insect carcasses also provided ions for SRB, which in turn infested the insects (Peñalver et al., 1996; Briggs et al., 2005), mediating the precipitation of minerals, mainly microframboidal pyrite, which covered the internal soft tissues (Fig. 9 and Fig. 13E of Barling et al., 2015). Microframboidal pyrite also infilled internal cavities (Figs. 3E, F) with remaining organic matter derived from partially decayed soft tissues (Orr, Briggs \& Kearns, 2008; Pan, Sha \& Fürsich, 2014). Therefore, distinct soft tissues had variable preservational potentials (Briggs \& Kear, 1993; Duncan \& Briggs, 1996) and/or fossilisation processes varied along carcasses (Gabbott et al., 2004). The preservational process is summarised in Fig. 10. The occurrence of coarse framboidal pyrite and fine microframboidal pyrite pseudomorphs can be interpreted as the result of the balance between ion (iron and sulphate) diffusion and pyrite nucleation rates (Sagemann et al., 1999; Butler \& Rickard, 2000; Gabbott et al., 2004). Initially, several pyritic nuclei likely formed owing to an initial high oversaturation of 
345 iron and sulphate present in pore water solutions, thus yielding framboids, as proposed for

346 framboid formation in Chengjiang biota fossils and in Jehol biota insects (Gabbott et al., 2004;

347 Ohfuji \& Rickard, 2005; Wang et al., 2012; Schiffbauer et al., 2014). Moreover, the barrier

348 created by the cuticle, the biofilms (around and inside carcasses), and the already formed

349 authigenic pyrite crystals presumably restricted ion diffusion (lower than nucleation rate) (e.g.

350 MacLean et al., 2008) and, thus, also favoured the precipitation of framboidal pyrite, instead of

351 isolated crystals (Gabbott et al., 2004). Nevertheless, in comparison to innermost carcass areas,

352 the cuticle received a continuous influx of iron and sulphate from the sediment, which favoured

353 coarse framboid formation, while finer microframboidal pyrite precipitated within the inner

354 cavities of the carcasses owing to the decreasing influx of iron and sulphate inward. Indeed,

355 initial pyrite saturation and ion diffusion timing can control mineral size (Sawlowicz, 1993;

356 Gabbott et al., 2004; Schiffbauer et al., 2014). Furthermore, the high decay potential of labile

357 internal tissues (e.g. muscles; Fig. 9) also led to an initial increase in $\mathrm{H}_{2} \mathrm{~S}$ saturation (Schiffbauer

358 et al., 2014) and, thus, high nucleation rates and microframboid formation inside the insect

359 carcasses, as suggested by Gabbott et al. (2004) to the preservation of the Chengjiang biota. The

360 rapid exhaustion of highly decay-prone organic matter by SRB would limit sulphide production

361 and further crystal growth, accounting for microframboid minute size (Gabbott et al., 2004).

362 Geochemical analyses revealed the preferential concentration of copper, zinc, and lead in

363 fossils in comparison to the surrounding matrix. The different abundance of some elements

364 between fossils and their embedding rock has been extensively attributed to the activity of

365 bacterial biofilms, which envelop decaying carcasses and leads to their mineralisation (Wilby et

366 al., 1996; Toporski et al., 2002; Westall et al., 2006; Laflamme et al., 2011). Copper, zinc, and

367 lead are able to bond to organic matter (Šípková et al., 2013). Alternatively, the preferable

368 association of copper and zinc to the carcasses can be attributed to bacterial activity. Indeed,

369 chitinous substrates buried in sediments are able to remove heavy metals from contaminated 
370

371

372

373

374

375

376

377

378

379

380

381

382

383

384

385

386

387

388

389

390

391

392

393

environments, a process mediated by bacteria (Kan et al., 2013). In this sense, the high chemical

affinity of copper and zinc with chitin (Neugebauer, 1986) further explains the presence of these

metals associated with the insects. Moreover, the adsorption of $\mathrm{Cu}^{2+}$ to chitin varies in response to pH gradients (Gonzalez-Davila \& Millero, 1990), which is controlled by biofilms, as already mentioned. The higher lead concentration in the fossils than in the limestone may be related to the association of this element with iron oxide/hydroxides, as reported in an Archaeopteryx sample (Bergmann et al., 2010), although no causal relationship has been attributed to explain this preferential association. This may also be explained by SRB activity on and within the insect carcasses yielding authigenic precipitation of galena (Lambrez et al., 2000).

Local variations of $\mathrm{pH}$ created during anaerobic decay control mineralisation, with acid conditions leading to phosphate precipitation, while higher $\mathrm{pH}$ values accounts for carbonate mineralisation (Briggs \& Wilby, 1996; Sagemann et al., 1999). In this vein, other authors suggested that the preservation of internal non-cuticular soft tissues of the Crato Member insects has occurred by phosphatisation (e.g. Barling et al., 2015), similarly to the preservation of labile tissues within a Jurassic horseshoe crab (Briggs et al., 2005), although direct quantitative evidence has not been revealed until SXS data herein provided. The preferential association of apatite to the fossils also points to microbial activity during fossilisation, as noticed elsewhere (Briggs et al., 2005). Only calcium poor continental waters have enough high concentrations of phosphate in solution to enable phosphatisation (Martínez-Delclòs, Briggs \& Peñalver, 2004), which was not the case of the Crato Member palaeolake. Therefore, alternative sources, such as the decay of organic matter (Allison, 1988b; Briggs, 2003) might have resulted in a high offer of phosphorus (and phosphate) for fossil insect phosphatisation. This process may have been facilitated by the activity of phosphate solubilizing bacteria (Kan et al., 2013; Martínez-Delclòs, Briggs \& Peñalver, 2004). 
395 lithification rate and, possibly, by exoskeleton microcracks generated by compaction (Figs. 10

396 and 11). This latter process is an explanation for the preservation of internal tissues in a Jurassic

397 horseshoe crab (Briggs et al., 2005), wherein the infestation of bacteria was also facilitated by

398 predation or diseases. Indeed, predation and partial disarticulation of some insects could have

399 facilitated bacteria infestation and the diffusion of ion rich solutions. This mechanism could

400 account for the occurrence of partially disarticulated and fragmented fossil insects, but still with

401 fine details preserved (e.g. Barling et al., 2015) and with some degree of three-dimensionality due

402 to early mineralisation.

403 The small size of the microframboidal pyrite pseudomorphs $(\sim 1 \mu \mathrm{m}$ in diameter $)$ explains

404 the high fidelity of internal soft-tissue preservation (Briggs, 2003; Delgado et al., 2014), as

405 observed in a taphonomic experiment carried out by Briggs \& Kear (1993). We suggest that total

406 carcass collapse was initially prevented by exoskeleton and internal tissue mechanical resistance

407 to compression (Peñalver et al., 1996; Orr, Briggs \& Kearns, 2008; Pan, Sha \& Fürsich, 2014).

408 Thereafter, further compaction was likely prevented by carcass mineralisation (Martínez-Delclòs,

409 Briggs \& Peñalver, 2004), yielding three-dimensional insect replicas (Fig. 11), as suggested for

410 the Jehol biota insects (Wang et al., 2012; Pan, Sha \& Fürsich, 2014) and for Miocene insects

411 from Spain (Peñalver et al., 1996).

412 The exceptional preservation of Crato Member insects reflects palaeoenvironmental 413 conditions. Isotopic analyses of carbonate carbon and oxygen performed in the Crato Member

414 basalmost laminated limestones revealed that the depositional palaeoenvironment was a

415 freshwater stratified lake poorly connected with external water sources, with stagnant, anoxic,

416 and at least episodic hypersaline bottom waters (Heimhofer \& Martill, 2007; Martill, Loveridge

$417 \&$ Heimhofer, 2007; Heimhofer et al., 2010). Water column stratification may have been related

418 to stagnation and/or high rates of surface water primary productivity providing a high amount of 
419 organic matter, the decay of which by aerobic bacteria reduced bottom water oxygen and

420 eventually led to anaerobic conditions in deep waters (Heimhofer \& Martill, 2007). Furthermore,

421 the occurrence of salt pseudomorphs and xerophytic vegetation pollen supports a semi-arid to

422 arid palaeoclimate (Heimhofer \& Martill, 2007).

423 Melendez et al. (2012) proposed the influence of photic zone euxinia (PZE) to the

424 preservation of biomarkers and to exceptional fossil preservation (Heimhofer \& Martill, 2007).

425 The isorenieratene biomarker was reported in the Crato Member laminated limestones by

426 Heimhofer \& Martill (2007). This pigment is used by green sulphur bacteria (Chlorobiaceae) in

427 anoxygenic photosynthesis (Schwark, 2013). This implies that the palaeoenvironment was, at

428 least, temporarily stratified in relation to $\mathrm{O}_{2}$ and $\mathrm{H}_{2} \mathrm{~S}$ yielding euxinic photic zone (EPZ), being

$429 \mathrm{H}_{2} \mathrm{~S}$ likely produced by SRB within the sediment (Heimhofer \& Martill, 2007). Following this

430 rationale, degradation was diminished after carcasses entered the EPZ since the blockage of

431 autolysis is triggered by reduction and/or anoxic conditions (Raff et al., 2008).

432 Menon \& Martill (2007) presented data showing that Crato Member insect taxonomic

433 diversity is dominated (around 60\%) by groups that may depend on aquatic habitats, such as bugs

434 (Hemiptera), mayflies (Ephemeroptera), dragonflies (Odonata), and flies (Diptera). This pattern

435 may reflect both high number of individuals inhabiting the uppermost freshwater oxygenated

436 waters (Menon \& Martill, 2007) and/or a taphonomic bias. Aquatic insects would have had the

437 advantage of inhabiting the depositional setting thus facilitating fossilisation, which is in

438 agreement with the preponderance of groups relying on aquatic environments found in carbonate

439 beds (Martínez-Delclòs, Briggs \& Peñalver, 2004). Moreover, hypersalinity episodes that have

440 affected the Crato palaeolake plus occasional water mixing could have caused poisoning of once

441 freshwater oxygenated shallow waters by $\mathrm{H}_{2} \mathrm{~S}$, leading to aquatic insect mass mortality (e.g.

442 Martins-Neto \& Gallego, 2006), thus yielding a significant record of aquatic insects. 
443 Additionally, anoxic conditions prevailing in the waterbody would have inhibited macro-

444 scavenger proliferation, facilitating carcass preservation (Heimhofer \& Martill, 2007).

445 Moreover, the palaeoenvironmental stratification in respect of oxygen and salinity likely

446 favoured fossil preservation (Heimhofer et al., 2007). The absence of burrowers (together with

447 grazers and scavengers) in the palaeolake owing to its stratification (Heimhofer \& Martill, 2007;

448 Menon \& Martill, 2007) accounts for the lack of bioturbation, which have favoured

449 mineralisation. Indeed, diffusion of $\mathrm{O}_{2}$, sediment hydration, and aerobic decay of $\mathrm{C}_{\text {org }}$ were

450 prevented (Callow \& Brasier, 2009) resulting in a zone of ionic saturation, heterotrophic

451 anaerobic activity, then yielding the early precipitation of authigenic minerals, like phosphates

452 and pyrite (Gehling, 1999; Callow \& Brasier, 2009; Laflamme et al., 2011; G. L. Osés et al.,

453 unpublished data). Similarly, bioturbation was proposed as a control for the pyritisation of insects

454 from the also lacustrine Jehol biota (Wang et al., 2012; Pan, Sha \& Fürsich, 2014). In addition to

455 the lack of bioturbation, the protection of the water-sediment interface against storms likely

456 contributed to substrate anoxia (Gehling, 1999; Heimhofer \& Martill, 2007). Furthermore, the

457 development of SRB biofilms around insect carcasses at the palaeolake bottom, followed by

458 carcass mineralisation, would have been enabled, for instance, by the lack of grazers in the water-

459 sediment interface (Menon \& Martill, 2007). Indeed, the importance of microorganisms, of high

460 salinity, and of the lack of scavengers to the preservation of three-dimensional fossil insects was

461 already noticed by Duncan and Briggs (1996) for the preservation of Riversleigh (Tertiary,

462 Australia) 3D insects. The role of microbial mats to three-dimensional insect preservation in

463 palaeolakes was then extended to the Jehol biota and the Crato Member (Wang et al., 2012;

464 Barling et al., 2015).

465 Nevertheless, the above discussed factors cannot fully explain pyritisation. The Crato

466 Member fossil insects are typically found in laminated limestone facies with a poor content of

467 organic matter (Neumann et al., 2003). Jehol biota pyritised insects (Wang et al., 2012) and 
468 Chengjiang biota pyritised arthropods, sponges, brachiopods, and other organisms (Gabbott et al., 469 2004) are also exclusive to organic-poor lithologies. In this way, the formation of pyrite is 470 concentrated in the carcasses and not widespread within the sediment (Gabbott et al., 2004),

471 which, therefore, we extend to the Crato Member (Martínez-Delclòs, Briggs \& Peñalver, 2004).

472 The fossil insects from the Crato Member are the first record of these organisms in 473 lacustrine laminated limestones preserved by pyrite without a volcanogenic sediment origin, as it 474 has been suggested for the preservation of the Jehol biota insects (Wang et al., 2012; Pan, Sha \& 475 Fürsich, 2014). These authors argued that iron and sulphur were nourished by volcanic material, 476 deposited at a siliciclastic-bearing lacustrine system. Nevertheless, Wang et al. (2012) considered 477 the role of heterotrophic bacteria as central for insect pyritisation, which was put on debate by 478 Pan, Sha \& Fürsich (2014). However, for the Crato Member, sulphate was likely provided by 479 evaporites (Martill et al., 2007). Anyway, despite commonly preserved in continental setting 480 limestones fossil insects are rarely pyritised given the scarcity of sulphate available in such 481 depositional environments (Martínez-Delclòs, Briggs \& Peñalver, 2004).

Finally, SEM, EDS, EDXRF, PIXE, and Raman analyses (Figs. 3-6, 8, Fig. S1) suggest

483 that the supergene oxidation and/or hydration of pyrite resulted in the formation of iron 484 oxides/hydroxides (Sawlowicz \& Kaye, 2006; Menon \& Martill, 2007; Wang et al., 2012; 485 Delgado et al., 2014; Pan, Sha \& Fürsich, 2014).

\section{Conclusions}

The results of imaging and geochemical techniques suggest that Crato Member fossil insects have been preserved by framboidal pyrite. Based on such evidence, we propose that the diffusion of pore water solutions to and through insect carcasses and their envelopment and

490 infestation by bacteria created microenvironmental geochemical conditions which led to the 491 mineralisation (mainly pyritisation) of insect cuticles and internal soft tissues. These 
492 geobiological/taphonomic processes have yielded three-dimensional replicas of insects, keeping

493 morphological details of delicate features (e.g. muscle fibres), which can shed light on taxonomy, 494 systematics, and palaeoecology.

495 Despite of pyrite genesis being ubiquitous, pyritisation of labile tissues is rare and 496 restricted to few examples in the fossil record (e.g. Briggs, Bottrell \& Raiswell, 1991; Gabbott et 497 al., 2004; Wang et al., 2012). Indeed, the exceptional preservation of the Crato Member fossil 498 insects confirms the importance of the following factors to the formation of Lagerstätten: early 499 diagenetic precipitation of pyrite (Gabbott et al., 2004; Wang et al., 2012; Barling et al., 2015) 500 under stratified lake conditions with low energy and without bioturbators (Gehling, 1999; Wang 501 et al., 2012), associated with microbial activity (Duncan \& Briggs, 1996; Wang et al., 2012;

502 Delgado et al., 2014; Barling et al., 2015; Catto et al., 2016), and fine sediments (Gehling, 1999) 503 with low organic matter contents (Neumann et al., 2003).

\section{Acknowledgements}

We thank the Department of Federal Police of Brazil for intelligence service and proactive initiatives, which have diminished the illegal international trade of fossils from the Santana

507 Formation, in the last years. These actions have increased the palaeontological collections of 508 Brazilian universities (e.g. University of São Paulo) in thousands of specimens, providing an 509 unprecedented amount of exceptionally well preserved fossils for Brazilian researchers and 510 foreign collaborators, hence contributing to the development of Brazilian palaeontological 511 research. Most of this material is already legally available for research. We are very grateful to 512 the huge effort made by the staff headed by Professor Paulo Eduardo de Oliveira, Professor 513 Juliana Moraes de Leme Basso, and Ivone Cardoso Gonzales, which improved the infrastructure 514 of the Scientific Palaeontological Collection of the Institute of Geosciences from the University 515 of São Paulo (São Paulo, Brazil), enabling proper fossil storage and organisation. We would like 
516 to acknowledge the Astrobiology Laboratory (Institute of Astronomy, Geophysics, and

517 Atmospheric Sciences, University of São Paulo, USP) for Raman analyses, the Institute of

518 Physics (USP) for EDXRF analyses, the Laboratory of Materials and Ionic Beams (Institute of

519 Physics, USP) for PIXE analyses, the Laboratory of Technological Plasmas (São Paulo State

520 University) and the Brazilian Nanotechnology National Laboratory for having kindly offered

521 their SEM equipment, and finally, the Brazilian Synchrotron Light Laboratory for SXS analyses.

522 We also would like to thank the graduation programs Ecologia e Recursos Naturais (PPGERN)

523 and Biotecnologia e Monitoramento Ambiental (PPGBMA), from UFSCar-Sorocaba, besides the

524 graduation program Geoquímica e Geotectônica, from USP. We are also grateful to Professor

525 Martin David Brasier, in memorian, for his stimulating and insightful ideas and to Professor

526 Thomas Rich Fairchild for enlightening discussions. We thank the graduate student Gustavo

527 Evangelista Prado for having kindly offered a vectorised version of his geologic map of the

528 Araripe Basin. We also thank Evandro Pereira da Silva for technical support during Raman

529 spectra acquisition, Evelyn Aparecida Mecenero Sanchez for support in figure preparation, and

530 Hugo Silva Pires Junior for skilful sample preparation. We acknowledge Graciela Piñeiro, PeerJ

531 Academic Editor, and the reviewers Bo Wang and Andre Nel, whose comments have improved

532 our original manuscript. We are also thankful for the language revision made by Izabel Maria da

533 Silva Ladeira from English for You (São Paulo, Brazil).

\section{References}

535 Abbate M, Vicentin FC, Compagnon-Cailhol V, Rocha MC, Tolentino HCN. The soft X-ray 536 spectroscopy beamline at the LNLS: technical description and commissioning results. J 537 Synchrotron Radiat. 1999; 6 (5): 964-972.

538 Allison PA. Taphonomy of the Eocene London Clay. Palaeontology. 1988a; 31 (4): 1079-1100. 
539 Allison PA. Phosphatized soft-bodied squids from the Jurassic Oxford Clay. Lethaia. 1988b; 21

540 (4): 403-410.

541 Anderson EP. 2012. Insect taphonomy in the Green River Formation of Colorado: preservation as 542 carbonaceous compressions and iron oxides [paper no. 8]. Geological Society of 543 America Abstracts with Programs 44 (7): 397. Available at http://www.italianplants.com 544 (accessed 8 September 2016).

545 Assine ML. Bacia do Araripe. Bol. Geoc. Petr. 2007; 15 (2): 371-389.

546 Barling N, Martill DM, Heads SW, Gallien F. High fidelity preservation of fossil insects from the 547 Crato Formation (lower Cretaceous) of Brazil. Cret Res. 2015; 52 (B): 605-622.

548 Bergmann U, Morton RW, Manning PL, Sellers WI, Farrar S, Huntley KG, Wogelius RA, Larson 549 P. Archaeopteryx feathers and bone chemistry fully revealed via synchrotron imaging. Proc Natl 550 Acad Sci U S A. 2010; 107 (20): 9060-9065.

551 Berner RA. Sedimentary pyrite formation: an update. Geochim Cosmochim Acta. 1984; 48: 605$552 \quad 615$.

553 Beurlen KA. Geologia da Chapada do Araripe. An Acad Bras Cienc. 1962; 34 (3): 365-370.

554 Beurlen K. As condições ecológicas e faciológicas da Formação Santana na Chapada do Araripe 555 (Nordeste do Brasil). An Acad Bras Cienc. 1971; 43: 411-415.

556 Briggs D. The role of decay and mineralization in the preservation of soft-bodied fossils. Annu 557 Rev Earth and Planet Sci. 2003; 31: 275-301.

558 Briggs DEG, Bottrell SH, Raiswell R. Pyritization of soft-bodied fossils: Beecher's Trilobite Bed 559 Upper Ordovician, New York State. Geology. 1991; 19: 1221-1224. 
560 Briggs DEG, Raiswell R, Bottrell SH, Hatfield DT, Bartels C. Controls on pyritization of

561 exceptionally preserved fossils: an analysis of the Lower Devonian Hunsrück Slate of Germany.

562 Am. J. Sci. 1996; 296: 633-663.

563 Briggs DEG, Kear AJ. Fossilization of soft tissue in the laboratory. Science. 1993; 259: 1439-

5641442.

565 Briggs DEG, McMahon S. The role of experiments in investigating the taphonomy of exceptional 566 preservation. Palaeontology. 2016; 59: 1-11.

567 Briggs DEG, Moore RA, Shultz JW, Schweigert G. Mineralization of soft-part anatomy and 568 invading microbes in the horseshoe crab Mesolimulus from the Upper Jurassic lagerstätte of 569 Nusplingen, Germany. Proc Biol Sci. 2005; 272: 627-632.

570 Briggs DEG, Wilby PR. The role of the calcium carbonate-calcium phosphate switch in the 571 mineralization of soft-bodied fossils. J Geol Soc London. 1996; 153: 665-668.

572 Brito-Neves BB. A Bacia do Araripe no contexto geotectônico regional. In: Atas do I Simpósio 573 sobre a Bacia do Araripe e Bacias Interiores do Nordeste; 1990. 1: 21-33.

574 Brock F, Parkes RJ, Briggs DEG. Experimental pyrite formation associated with decay of plant 575 material. Palaios. 2006; 21: 499-506.

576 Butler IB, Rickard D. Framboidal pyrite formation via the oxidation of iron (II) monosulphide by

577 hydrogen sulphide. Geochim Cosmochim Acta. 2000; 64 (15): 2665-2672.

578 Butterfield NJ. Secular distribution of Burgess-Shale-type preservation. Lethaia. 1995; 28: 1-13. 
579 Callow RHT, Brasier MD. Remarkable preservation of microbial mats in Neoproterozoic 580 siliciclastic settings: Implications for Ediacaran taphonomic models. Earth-Sci. Rev. 2009; 96: $581207-219$.

582 Canfield DE, Raiswell R. Pyrite formation and fossil preservation. In: Allison PA, Briggs DEG, 583 editors. Topics in Geobiology. Plenum Press; 1991, pp. 337-387.

584 Catto B, Jahnert RJ, Warren LV, Varejao FG, Assine ML. The microbial nature of laminated 585 limestones: lessons from the Upper Aptian, Araripe Basin, Brazil. Sediment Geol. 2016; doi: 586 10.1016/j.sedgeo.2016.05.007.

587 Characklis WG, Wilderer PA. Glossary. In: Characklis WG, Wilderer PA (eds) Structure and 588 function of biofilms. Wiley, Chichester; 1989. pp. 369-371.

589 Chen L, Xiao S, Pang K, Zhou C, Yuan X. Cell differentiation and germ-soma separation in 590 Ediacaran animal embryo-like fossils. Nature. 2014; 516: 238-241.

591 Coimbra JC, Arai M, Carreño AL. Biostratigraphy of lower Cretaceous microfossils from the 592 Araripe Basin, northeastern Brazil. Geobios. 2002; 35 (6): 687-698.

593 Coleman ML, Hedrick DB, Lovley DR, White DC, Pye K. Reduction of Fe (III) in sediments by 594 sulphate-reducing bacteria. Nature. 1993; 361: 436-438.

595 Défarge C, Trichet J, Jaunet A-M, Robert M, Tribble J, Sansone FJ. Texture of microbial 596 sediments revealed by cryo-scanning electron microscopy. J Sediment Res. 1996; 66 (5): 935 597947. 
598 Delgado A de O, Buck PV, Osés GL, Ghilardi RP, Rangel EC, Pacheco MLAF. Paleometry: a 599 brand new area in Brazilian science. Mater Res. 2014; 17: 1434-1441.

600 Duncan IJ, Briggs DEG. Three-dimensionally preserved insects. Nature. 1996; 381: 30-31.

601 Duncan IJ, Briggs DEG, Archer M. Three-dimensionally mineralised insects and millipedes from 602 the Tertiary of Riversleigh, Queensland, Australia. 1998; 41 (5): 835-851.

603 Dupraz C, Reid RP, Braissant O, Decho AW, Norman RS, Visscher PT. Processes of carbonate 604 precipitation in modern microbial mats. Earth-Sci Rev. 2008; 96 (3): 141-162.

605 Engel MS, Grimaldi D \& Krishna K. Primitive termites from the Early Cretaceous of Asia 606 (Isoptera). Stuttgarter Beiträge zur Naturkunde, Serie B (Geologie und Paläontologie). 2007; 371: $607 \quad 1-32$.

608 Faria DLA, Lopes FN. Heated goethite and natural hematite: can Raman spectroscopy be used to 609 differentiate them? Vib Spectrosc. 2007; 45: 117-121.

610 Forchielli A, Steiner M, Kasbohm J, Hu S, Keupp H. Taphonomic traits of clay-hosted early 611 Cambrian Burgess Shale-type fossil Lagerstätten in South China. Palaeogeogr. Palaeoclimatol. 612 Palaeoecol. 2014; 398: 59-85.

613 Gabbott SE, Xian-guang H, Norry MJ, Siveter DJ. Preservation of early Cambrian animals of the 614 Chengjiang biota. Geology. 2004; 32 (10): 901-904.

615 Gehling JG. Microbial mats in terminal Proterozoic siliciclastics: ediacaran death masks. Palaios 616 Res. Rep. 1999; 14: 40-57.

617 Gonzalez-Davila M, Millero FJ. The adsorption of copper to chitin in seawater. Geochim 618 Cosmochim Acta. 1990; 54: 761-768. 
619 Grimaldi D. 2003. Fossil Record. In: Resh VH \& Cardé RT, eds. Encyclopedia of Insects.

620 Elsevier, 396-403.

621 Grimaldi D, Engel MS. 2005. Evolution of the Insects. New York: Cambridge University Press.

622 Grimaldi D, Maisey J. Introduction. In: Gimaldi D, editor. Insects from the Santana Formation,

623 Lower Cretaceous, of Brazil. Bull. AMNH; 1990. pp. 1-15.

624 Grimes ST, Davies KL, Butler IB, Brock F, Edwards D, Rickard D, Briggs DEG, Parkes RJ.

625 Fossil plants from the Eocene London Clay: the use of pyrite textures to determine the 626 mechanism of pyritization. J Geol Soc. 2002; 159: 493-501.

627 Heimhofer U, Ariztegui D, Lenniger M, Hesselbo SP, Martill DM, Rios-Netto AM. Deciphering 628 the depositional environment of the laminated Crato fossil beds (early Cretaceous, Araripe Basin, 629 north-eastern Brazil). Sedimentology. 2010; 57: 677-694.

630 Heimhofer U, Martill DM. The sedimentology and depositional environment of the Crato 631 Formation. In: Martill DM, Bechly G, Loveridge R, editors. The Crato fossil beds of Brazil: 632 window to an ancient world. Cambridge University Press; 2007. pp. 44-62.

633 Jarzembowski EA, Ross AJ. Insect Origination and Extinction in the Phanerozoic. In: Hart MB, 634 editor. Biotic Recovery from Mass Extinction Events. Geological Society Special Publication; $6351996, n^{\circ} 102$, pp. 65-78.

636 Kan J, Obraztsova A, Wang Y, Leather J, Scheckel KG, Nealson KH. Apatite and chitin 637 amendments promote microbial activity and augment metal removal in marine sediments. Open 638 J. Met. 2013; 3: 51-61.

639 Kellner AWA. Membro Romualdo da Formação Santana, Chapada do Araripe, CE: um dos mais 640 importantes depósitos fossíliferos do Cretáceo brasileiro. In: Schobbenhaus C, Campos DA, 641 Qeiroz ET, Winge M, Berbert-Born MLC, editors. Sítios geológicos e paleontológicos do brasil, 
642 Departamento Nacional da Produção Mineral/Companhia de Pesquisa de Recursos 643 Minerais/Comissão Brasileira de Sítios Geológicos e Paleobiológicos; 2002. pp. 121- 130.

644 Labandeira C. Why did Terrestrial Insect Diversity Not Increase During the Angiosperm 645 Radiation? Mid-Mesozoic, Plant-Associated Insect Lineages Harbor Clues. In: Pontarotti P, 646 editor. Evolutionary Biology: Genome Evolution, Speciation, Coevolution and Origin of Life. 647 Springer International Publishing Switzerland; 2014, pp. 261-299.

648 Laflamme M, Schiffbauer JD, Narbonne JM, Briggs DEG. Microbial biofilms and the 649 preservation of the Ediacara biota. Lethaia. 2011; 44: 203-213.

650 Lambrez M, Druschel GK, Thomsen-Ebert T, Gilbert B, Welch SA, Kemner KM, Logan GA, 651 Summons RE, De Stasio G, Bond PL, Lai B, Kelly SD, Banfield JF. Formation of sphalerite 652 (ZnS) deposits in natural Biofilms of sulfate-reducing bacteria. Science. 2000; 290: 1744-1777.

653 Leakey LSB. Lower Miocene invertebrates from Kenya. Nature. 1952; 169: 624.

654 Leri AC, Hay MB, Lanzirotti A, Rao W, Myneni SCB. Quantitative determination of absolute 655 organohalogen concentrations in environmental samples by X-ray absorption spectroscopy. Anal 656 Chem. 2006; 78: 5711-5718.

657 Lidgard S, Crane PR. Quantitative analyses of the early angiosperm radiation. Nature. 1988; 331: $658 \quad 344-346$.

659 Liu AG. Framboidal pyrite shroud confirms the 'death mask' model for moldic preservation of 660 ediacaran soft-bodied organisms. Palaios. 2016; 31: 259-274.

661 Love LG. Micro-organic material with diagenetic pyrite from the lower Proterozoic Mount Isa 662 shale and a carboniferous shale. Proc York Geol Soc. 1965; 35 (2), 9: 187-202. 
663 MacLean LCW, Tyliszczak T, Gilbert PU, Zhou D, Pray TJ, Onstott TC, Southam G. A high-

664 resolution chemical and structural study of framboidal pyrite formed within a low-temperature

665 bacterial biofilm. Geobiology. 2008; 6: 471-480.

666 Martill DM, Loveridge RF, Heimhofer U. Halite pseudomorphs in the Crato Formation (early

667 Cretaceous, late Aptian) Araripe Basin, northeast Brazil: further evidence for hypersalinity. Cret.

668 Res. 2007; 28 (4): 613-620.

669 Martínez-Delclòs X, Briggs DEG, Peñalver E. Taphonomy of insects in carbonates and amber.

670 Palaeogeogr. Palaeoclimatol. Palaeoecol. 2004; 203: 19-64.

671 Martins-Neto RG, Gallego OF. "Death behaviour" - thanatoethology, new term and concept: a

672 taphonomic analysis providing possible paleoethologic inferences. special cases from arthropods

673 of the Santana Formation (Lower Cretaceous, Northeast Brazil). Geoci. UNESP. 2006; 25 (2):

$674 \quad 241-254$.

675 McCobb LME, Duncan IJ, Jarzembowski EA, Stankiewicz BA, Wills MA, Briggs DEG.

676 Taphonomy of the insects from the Insect Bed (Bembridge Marls), late Eocene, Isle of Wight,

677 England. Geol. Mag. 1998; 135 (4): 553-563.

678 Melendez I, Grice K, Trinajstic K, Ladjavardi M, Greenwood P, Thompson K. Biomarkers reveal

679 the role of photic zone euxinia in exceptional fossil preservation: an organic geochemical

680 perspective. Geology. 2012 Nov 06. doi:10.1130/G33492.1.

681 Menon F, Martill DM. Taphonomy and Preservation of Crato Formation Arthropods. In: Martill 682 DM, Bechly G, Loveridge R, editors. The Crato fossil beds of Brazil: window to an ancient 683 world. Cambridge University Press; 2007. pp. 79-96.

684 Neugebauer E. The krill chitin and some aspects of metals transport in antarctic sea water. Pol 685 Polar Res. 1986; 371-376. 
686 Neumann VH, Borrego AG, Cabrera I, Dino R. Organic matter composition and distribution 687 through the Aptian-Albian lacustrine sequences of the Araripe Basin, northeastern Brazil. Int J 688 Coal Geol. 2003; 54: 21-40.

689 Nicholson DB, Mayhew PJ, Ross AJ. Changes to the Fossil Record of Insects Through Fifteen 690 Years of Discovery. PLoS ONE. 2015; 10(7): e0128554. doi:10.1371/journal.pone.0128554.

691 Ohfuji H, Rickard D. Experimental syntheses of framboids-a review. Earth-Sci Rev. 2005; 71: $692 \quad 147-170$.

693 Orr PJ, Briggs DEG, Kearns S. Taphonomy of exceptionally preserved crustaceans from the upper Carboniferous of southeastern Ireland. Palaios. 2008; 23: 298-312.

695 Palmer AR. Miocene Arthropods from the Mojave Desert California. Geological Survey 696 Professional Paper 294-G, United States Government Printing Office, Washington. 1957.

697 Pan Y, Sha J, Fürsich FT. A model for organic fossilization of the early Cretaceous Jehol 698 lagerstätte based on the taphonomy of "Ephemeropsis trisetalis". Palaios. 2014; 29: 363-377.

699 Peñalver E, De Renzi M, Martínez-Delclòs X, Querol X. Actividad fosildiagenética de bacterias 700 sulfato-reductoras en dípteros bibiónidos del Mioceno de Rubielos de Mora (Teruel, España). Un 701 caso de fosilización diferencial. In: Meléndez G, Blasco MF, Pérez I, editors. Comunicácion de la 702 II Reunión de Tafonomía y Fosilización, Institución Fernando el Católico, Zaragoza; 1996, pp. 703 299-303.

704 Peterson JE, Lenczewski ME, Scherer RP. Influence of microbial biofilms on the preservation of 705 primary soft tissue in fossil and extant archosaurs. PLoS ONE. 2010; 5 (10): e13334. 706 doi:10.1371/journal.pone.0013334. 
707 Popa R, Kinkle BK, Badescu A. Pyrite framboids as biomarkers for iron-sulfur systems.

708 Geomicrobiol J. 2004; 21 (3): 193-206.

709 Prado GMEM, Anelli LE, Petri S, Romero GR. New occurrences of fossilized feathers:

710 systematics and taphonomy of the Santana Formation of the Araripe Basin (Cretaceous), NE,

711 Brazil. PeerJ. 2016; 4:e1916 https://doi.org/10.7717/peerj.1916.

712 Raff EC, Schollaert KL, Nelson DE, Donoghue PCJ, Thomas C-W, Turner FR, Stein BD, Dong

713 X, Bengston S, Huldtgren T, Stampanoni M, Chongyu Y, Raff RA. Embryo fossilization is a

714 biological process mediated by microbial biofilms. Proc Natl Acad Sci U S A. $2008 ; 105$ (49):

715 19360-19365.

716 Sagemann J, Bale SJ, Briggs DEG, Parkes RJ. Controls on the formation of authigenic minerals

717 in association with decaying organic matter: an experimental approach. Geochim Cosmochim

718 Acta. 1999; 63 (7/8): 1083-1095.

719 Sawlowicz Z. Pyrite framboids and their development: a new conceptual mechanism. Geol

720 Rundsch. 1993; 82: 148-156.

721 Sawlowicz Z, Kaye TG. Replacement of iron sulphides by oxides in the dinosaur bone from the

722 Lance Fm. (Wyoming, USA) - preliminary study. Min. Pol. Spec. Pap. 2006; 29, 184-187.

723 Schiffbauer JD, Xiao S, Cai Y, Wallace AF, Hua H, Hunter J. A unifying model for

724 Neoproterozoic-Palaeozoic exceptional fossil preservation through pyritization and carbonaceous

725 compression. Nat Commun. 2014; 5: 5754. doi: 10.1038/ncomms6754.

726 Schlüter T, Kohring R, Gregor H-J. Dragonflies preserved in transparent gypsum crystals from

727 the Messinian (Upper Miocene) of Alba, northern Italy. A. Zool. Cracovien. 2002; 46: 373-379.

728 Schwark L. Exceptional preservation of microbial lipids in Paleozoic to Mesoproterozoic

729 sediments. Geology. 2013; 41: 287-288. 
730 Schwermann AH, Rolo TS, Caterino MS, Bechly G, Schmied H, Baumbach T, Kamp TV. 731 Preservation of three-dimensional anatomy in phosphatized fossil arthropods enriches 732 evolutionary inference. eLife. 2016.doi: http://dx.doi.org/10.7554/eLife.12129.

733 Seilacher A, Reif W-E, Westphal F. Sedimentological, ecological and temporal patterns of fossil 734 lagerstätten. Philos Trans R Soc Lond B Biol Sci. 1985; 311: 5-23.

735 Š́pková A, Száková J, Tlustoš P. Affinity of Selected Elements to Individual Fractions of Soil 736 Organic Matter. Water, Air \& Soil Pollution. 2013; 225: 1802.

737 Skei JM. Formation of framboidal iron sulfide in the water of a permanently anoxic fjord738 Framvaren, South Norway. Mar Chem. 1988; 23: 345-352.

739 Soares LPCM, Kerber BB, Osés GL, de Oliveira AM, Pacheco MLAF. Paleobiologia e evolução: 740 o potencial do registro fossilífero brasileiro. R Esp. 2013; 2: 24-40.

741 Szczepanik P, Sawłowicz Z, Bak M. Pyrite framboids in pyritized radiolarian skeletons (Mid742 Cretaceous of the Pieniny Klippen Belt, Western Carpathians, Poland). An Soc Geol Pol. 2004; $74374: 35-41$.

744 Toporski JKW, Steele A, Westall F, Avci R, Martill DM, McKay DS. Morphologic and spectral 745 investigation of exceptionally well-preserved bacterial biofilms from the Oligocene Enspel 746 formation, Germany. Geochim Cosmochim Acta. 2002; 66: 1773-1791.

747 Viana MS, Neumann VH. O Membro Crato da Formação Santana: riquíssimo registro de fauna e 748 flora do Cretáceo. In: Schobbenhaus C, Campos DA, Qeiroz ET, Winge M, Berbert-Born MLC, 749 editors. Sítios geológicos e paleontológicos do brasil, 5. Departamento Nacional da Produção 750 Mineral/Companhia de Pesquisa de Recursos Minerais/Comissão Brasileira de Sítios Geológicos 751 e Paleobiológicos; 2000. pp. 113- 120. 
752 Voigt E. Weichteile an fossilen Insekten aus der eozänen Braunkohle des Geiseltales bei Halle

753 (Saale). Nova Acta Leopoldina Deutschland. 1938; 6 (34): 3-38.

754 Wang B, Zhao F, Zhang H, Fang Y, Zheng D. Widespread pyritization of insects in the early

755 Cretaceous Jehol biota. Palaios. 2012; 27: 707-711.

756 Westall F, de Vries ST, Nijman W, Rouchon V, Orberger B, Pearson V, Watson J, Verchovsky A,

757 Wright I, Rouzaud J-N, Marchesini D, Severine A. The 3.466 Ga 'Kitty's Gap Chert,' an early

758 Archean microbial ecosystem. Geol Soc Am Spec Pap. 2006; 405: 105-131.

759 Wilby PR, Briggs DEG, Bernier P, Gaillard C. Role of microbial mats in the fossilization of soft

760 tissues. Geology. 1996; 24 (9): 787-790.




761 Figure 1: Geological setting of the Crato Member. Geological map of the Araripe Basin,

762 position of the Araripe Basin in the Brazilian territory, and simplified stratigraphic chart of the

763 Araripe Basin. Image credit: modified after Prado et al. (2016) (DOI:

764 https://doi.org/10.7717/peerj.1916/fig-1).

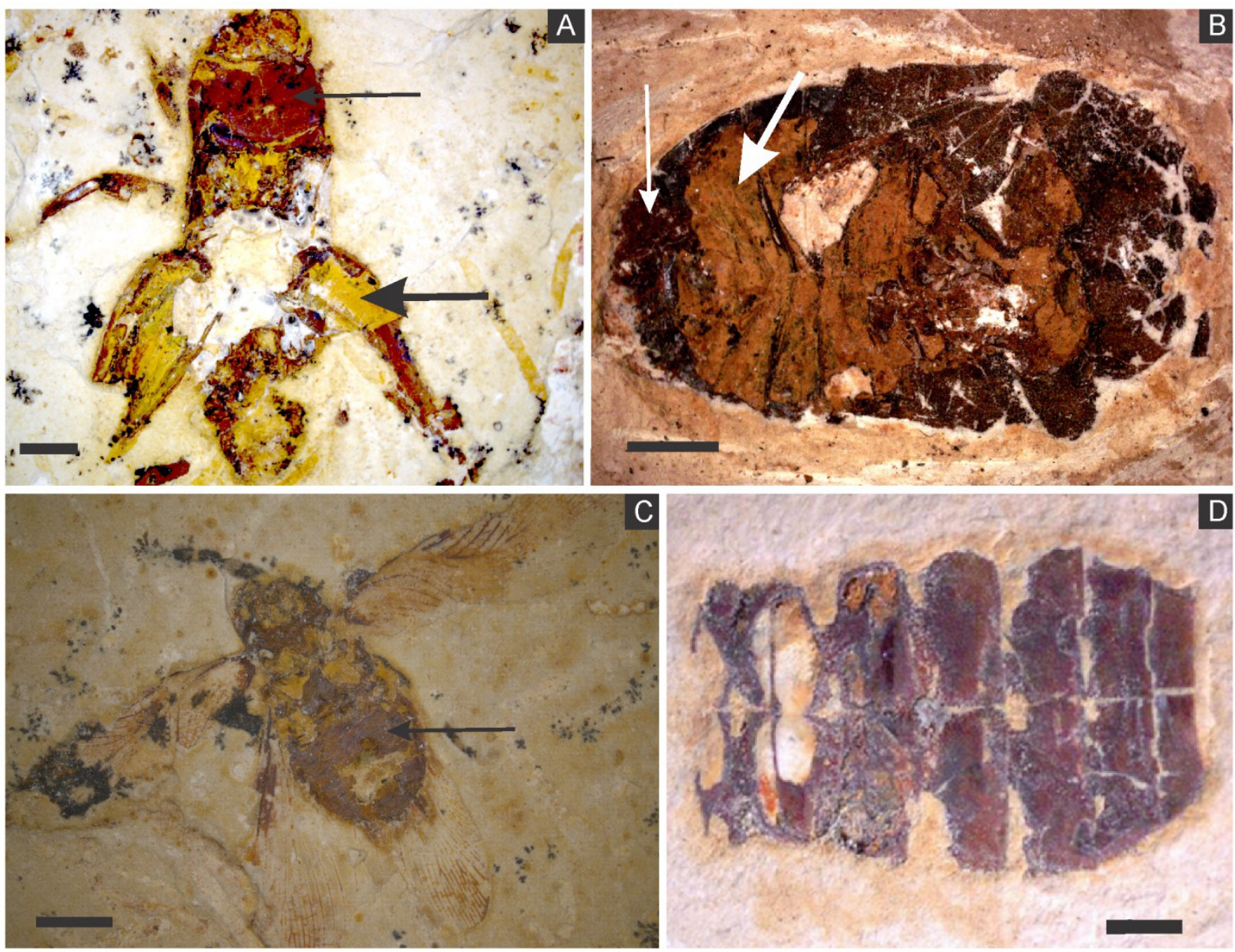

765 Figure 2: (A) orthopteran GP/1E 7105. (B) hemipteran GP/1E 8440. (C) blattodea GP/1E

766 9137. (D) specimen GP/1E 6820, cuticle of an undetermined insect. In A-C, exoskeleton is

767 indicated by narrow arrows and internal part is indicated by wide arrows. The brown, yellow, and 
768 orange-brown colours represent the alteration of originally precipitated pyrite (Barling et al.,

769 2015). Scale bars $=2 \mathrm{~mm}(\mathrm{~A}-\mathrm{C}), 1 \mathrm{~mm}$ (D). Figure A was modified from Delgado et al. (2014).

Figure 3: Scanning electron microscopy analysis for mineral characterisation of samples.

771 (A) blattodea GP/1E 9137 (Fig. 2C). Sub-spherical to spherical grains merge (1), yielding a

772 levelled surface (Grimes et al., 2002), which retains details of the outer cuticle area (2; e.g.

773 Barling et al., 2015). Scale bar $=10 \mu \mathrm{m}$. (B) GP/1E 8440 (Fig. 2B). Dissolution cavities

774 delimited by a mineralised template formerly occupied by crystals. Scale bar $=2 \mu \mathrm{m}$. (C) GP/1E

7758440 (Fig. 2B). Detail of the microtexture depicted in B. Scale bar $=2 \mu \mathrm{m}$. (D) GP/1E 9137 (Fig.

776 2C). In the cuticle, polygonal structures delimited by lamellae (arrow) occur. These are likely

777 composed by very fine grained pseudomorphs after pyrite. The lamellae are porous in some

778 portions (1 and 2). The polygonal structures are filled with nanocrystals similar to the ones

779 forming the sub-spherical to spherical grains (3) and with anhedral pseudomorphs of

780 microcrystalline pyrite $(<1 \mu \mathrm{m})$ (4). Scale bar $=10 \mu \mathrm{m}$. (E) GP/1E 8397 (Fig. 6A). The

781 microfabrics of the internal cavities are formed by sub-spherical to spherical generally loosely-

782 packed grains (of approximately $1 \mu \mathrm{m}$ in diameter), formed by nanocrystals (1) and sometimes

783 have smoothed surface (2). The latter is likely an oxidation feature of the former type. The arrow

784 depicts oxidation feature. Scale bar $=1 \mu \mathrm{m}$. (F) GP/1E 7105 (Fig. 2A). Some grains infilling

785 internal cavities are embedded in a smooth matrix (wide arrow) and form clusters without a

786 defined shape. "Weblike" structures are indicated by narrow arrows. These features are

787 interpreted as preserved extracellular polymeric substances (EPS). Scale bar $=2 \mu \mathrm{m}$. A-F are

788 secondary electron micrographs. A: Beam energy: $10 \mathrm{kV}$, work distance: $11 \mathrm{~mm}$, spot size: 15; B:

789 Beam energy: $10 \mathrm{kV}$, work distance: $8 \mathrm{~mm}$, spot size: 15; C: Beam energy: $10 \mathrm{kV}$, work distance:

$7908 \mathrm{~mm}$, spot size: 15; D: Beam energy: $10 \mathrm{kV}$, work distance: $11 \mathrm{~mm}$, spot size: 15. E: Beam

791 energy: $10 \mathrm{kV}$, work distance: $8 \mathrm{~mm}$, spot size: 15 . F: Beam energy: $10 \mathrm{kV}$, work distance: $8 \mathrm{~mm}$,

792 spot size: 15. 


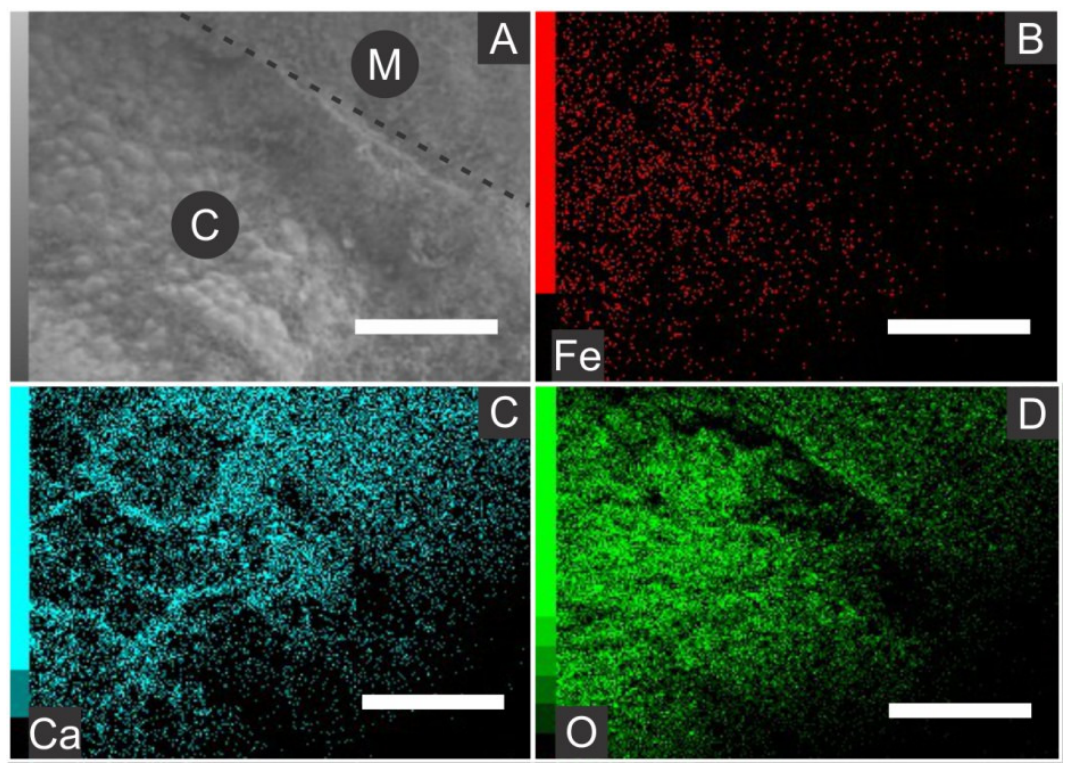

793 Figure 4: Energy dispersive X-ray spectroscopy elemental maps of the specimen GP/1E

7948440 (Fig. 2B). (A) Scanning electron microscopy secondary electron micrograph of the 795 specimen (matrix (M) and cuticle (C)). Beam energy: $10 \mathrm{kV}$, work distance: $8 \mathrm{~mm}$, spot size: 65.

796 (B) iron. (C) calcium. (D) oxygen. Scale bars $=0.5 \mathrm{~mm}$. 

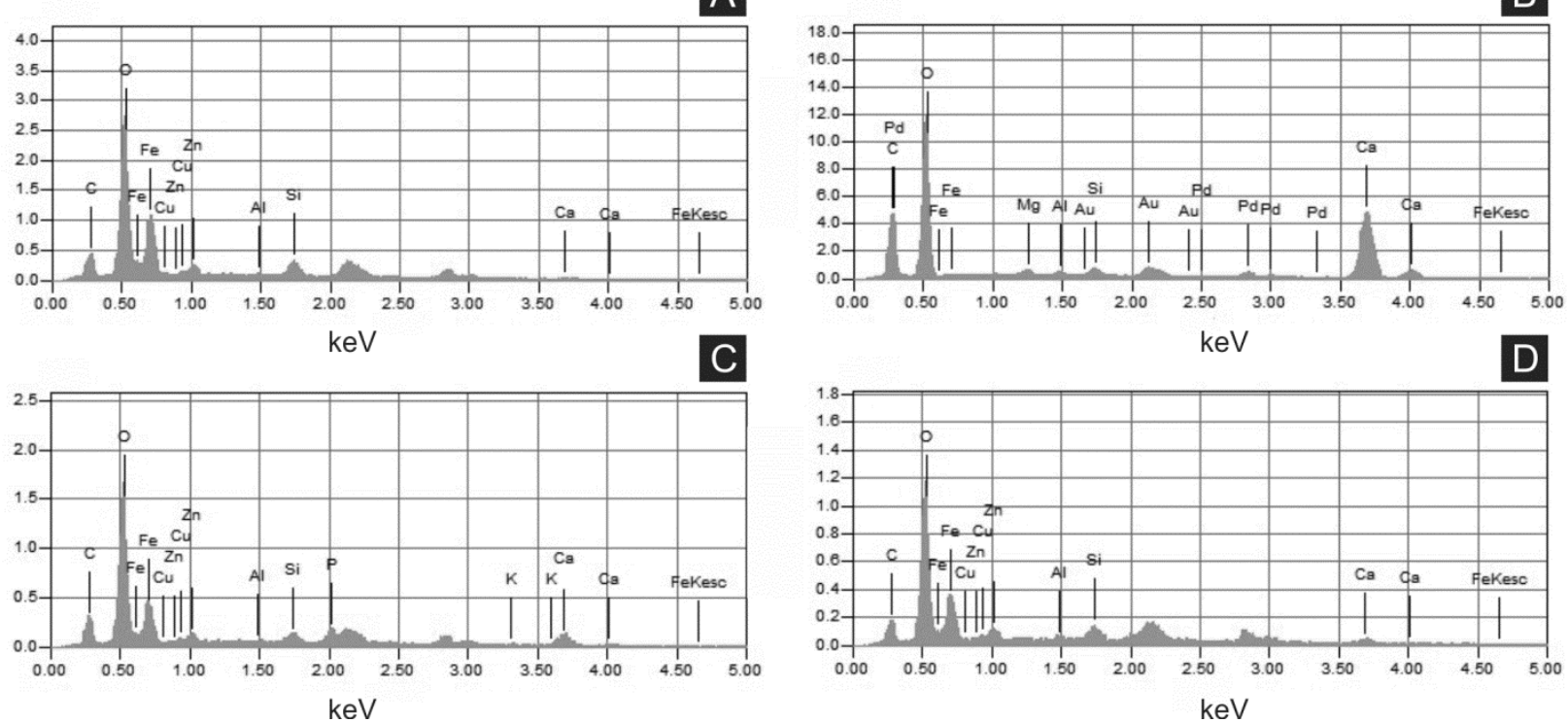

797 Figure 5: Energy dispersive X-ray spectroscopy point spectra. (A) GP/1E 8440 (Fig. 2B).

798 Cuticle. (B) GP/1E 7105 (Fig. 2A). Matrix. (C-D), GP/1E 8397 (Fig. 6A). Internal part of the fossil. 

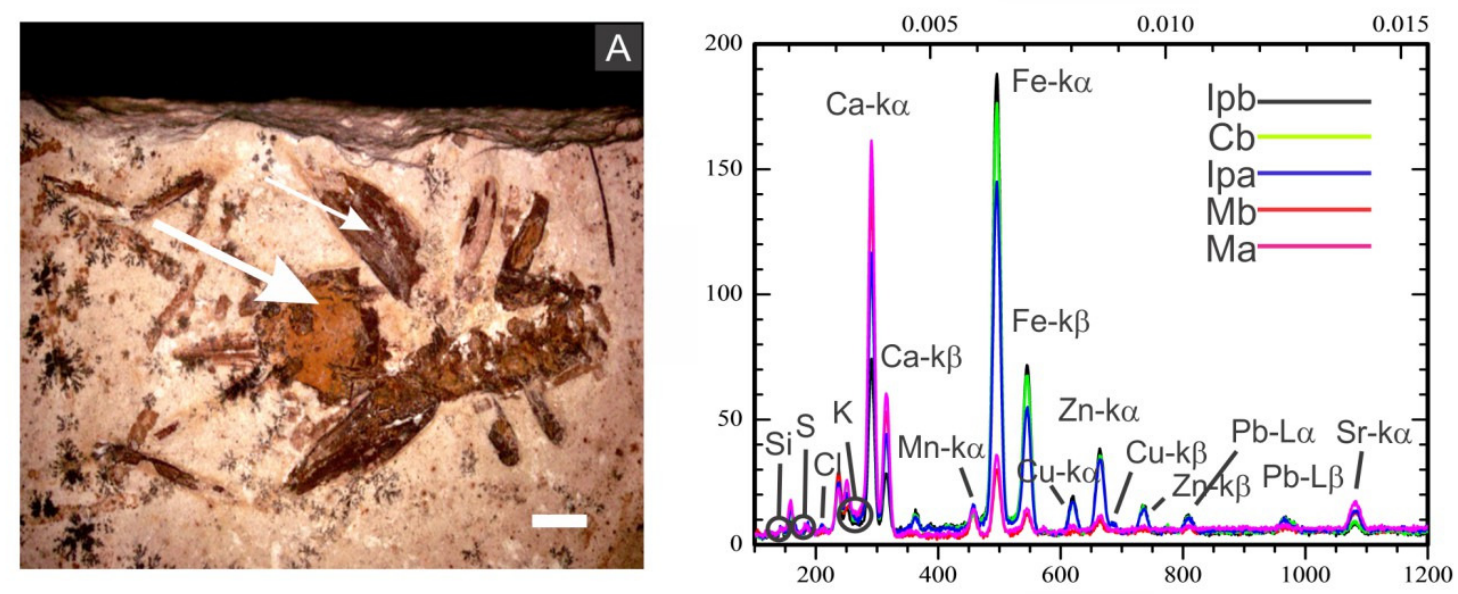

Channel



Channel
Energy $(\mathrm{MeV})$

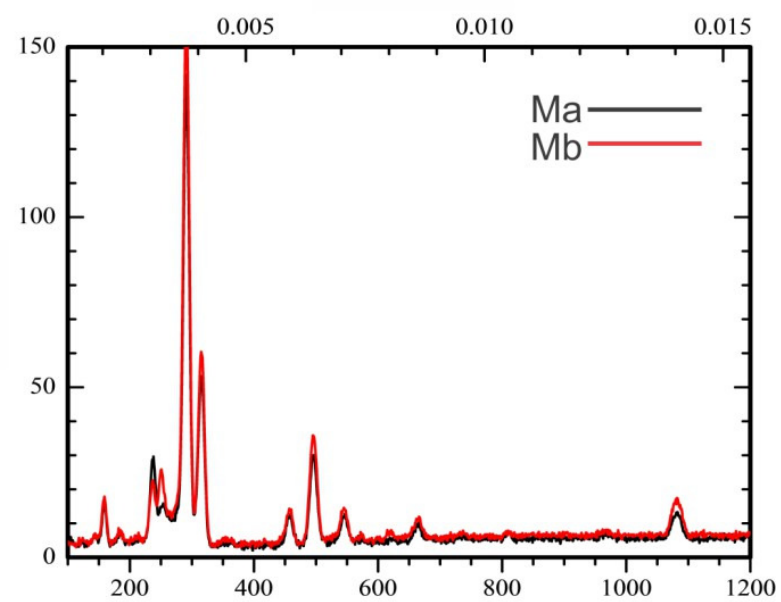

Channel

Figure 6: X-ray fluorescence spectra (EDXRF). (A) orthopteran GP/1E 8397. Cuticle is

801 indicated by narrow arrow, while internal portion is indicated by wide arrow. Scale bar $=2 \mathrm{~mm}$.

802 (B-D), EDXRF spectra of specimen in A (a) and of specimen GP/1E 8440 (b) (Fig. 2B). Ip =

803 internal portion, $\mathrm{C}=$ cuticle, and $\mathrm{M}=$ rock matrix. See $(\mathrm{B})$ for element/peak correlation for all 804 three spectra (B-D). 

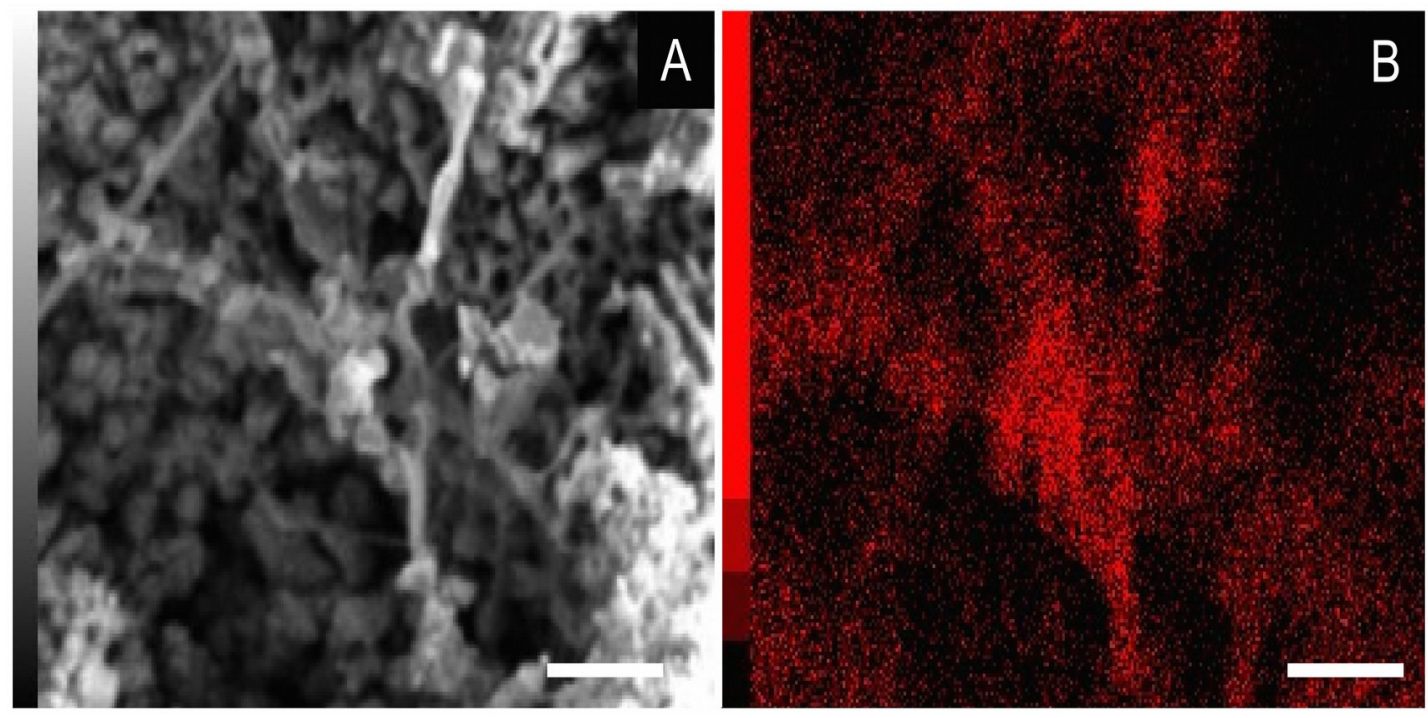

805 Figure 7: Energy dispersive X-ray spectroscopy elemental map of a "weblike" feature. (A)

806 GP/1E 8827 (Fig. S1). Scanning electron microscopy secondary electron micrograph of the

807 "weblike" (putative preserved extracellular polymeric substances) feature and the surrounding 808 pyrite pseudomorphs. Beam energy: $10 \mathrm{kV}$, work distance: $11 \mathrm{~mm}$, spot size: 65. (B) Carbon map 809 of the region showed in A. The colour pattern (carbon distribution) may, alternatively, reflect 810 sample topographic irregularities. Scale bars $=5 \mu \mathrm{m}$. 

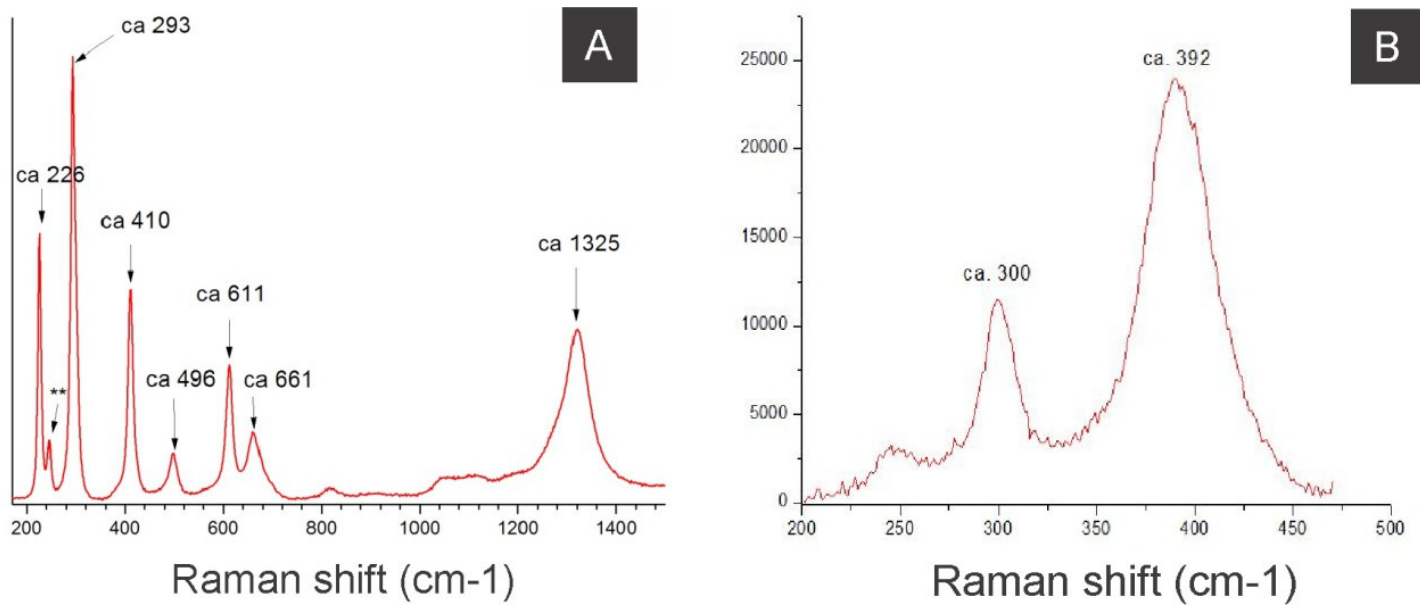

811 Figure 8: Raman spectra of insect cuticle. (A) spectrum of an iron oxide/hydroxide

812 (amorphous hematite or limonite (Faria \& Lopes, 2007)) of cuticle in Fig. 2D (** = ca 245). (B)

813 spectrum of goethite of the cuticle of the fossil GP/1E 8440 (Fig. 2B). A laser source of $785 \mathrm{~nm}$

814 was used in B and other laser source of $633 \mathrm{~nm}$ was used in A. A: magnification $=20 \mathrm{x}$, exposure

815 time $=20 \mathrm{~s}$, accumulation number $=30$, laser power $=1 \%$; B: magnification $=50 \mathrm{x}$ (long working

816 distance), exposure time $=10 \mathrm{~s}$, accumulation number $=30$, laser power $=0.05 \%$. 



817 Figure 9: Scanning electron microscopy micrographs of putative muscular fibres. (A-B)

818 GP/1E 7105 (Fig. 2A). (A) putative muscular fibres in a broken portion of the cuticle. Scale bar =

$81950 \mu \mathrm{m}$. (B) microfabric (arrows) associated with the putative muscular fibres. Scale bar $=10 \mu \mathrm{m}$.

820 A-B are secondary electron micrographs. A: Beam energy: $5.000 \mathrm{kV}$, spot size: 3.0 , work

821 distance: $14.5 \mathrm{~mm}$; B: Beam energy: $10.00 \mathrm{kV}$, spot size: 3.0 , work distance: $14.4 \mathrm{~mm}$. 


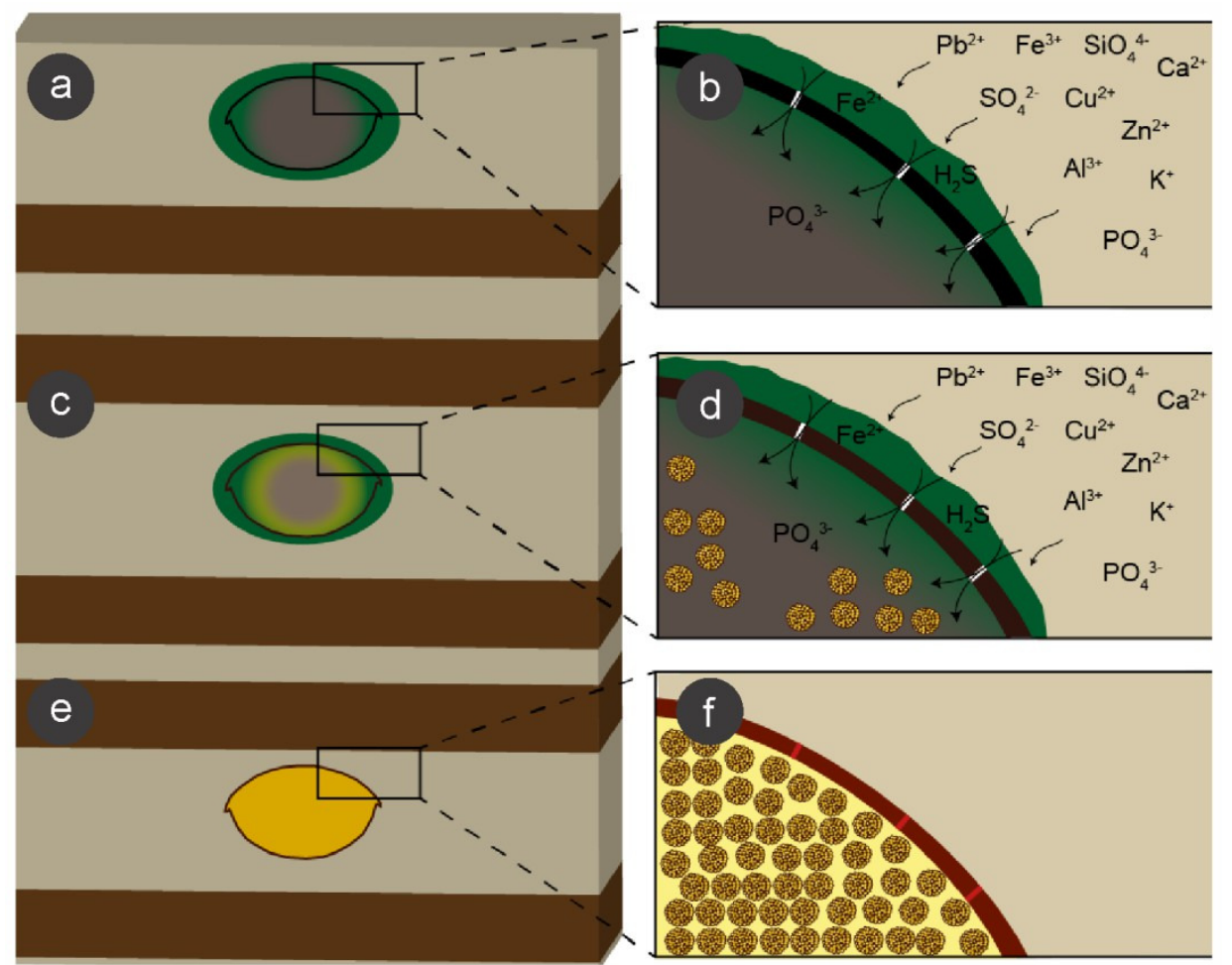

822 Figure 10: Process of preservation of the Crato Member fossil insects. After final burial (a),

823 ions present in sediment pore water solutions were concentrated in biofilms of sulphate reducing

824 bacteria (SRB) (green) around and within decaying carcasses. Both ions and bacteria entered 825 insects through microcracks (putatively generated by compaction) in the cuticle (black) (b).

826 These bacteria reduced sulphate and, possibly iron (III), resulting in framboidal pyrite formation,

827 which replaced cuticle (brown; c, d). Within the carcasses, labile tissues (grey) were also replaced

828 and replicated (or at least covered) by microframboidal pyrite (c, internal yellow halo and d,

829 internal yellow spheres). Total carcass collapse was initially avoided by structural strength of

830 both cuticle and internal soft tissues and later prevented by early lithification (Martínez-Delclòs,

831 Briggs \& Peñalver, 2004) of both exoskeleton and internal soft tissues (e, f), thus yielding three-

832 dimensional replicas. Microcracks were also filled with pyrite (f, red segments in the mineralised 833 cuticle). 


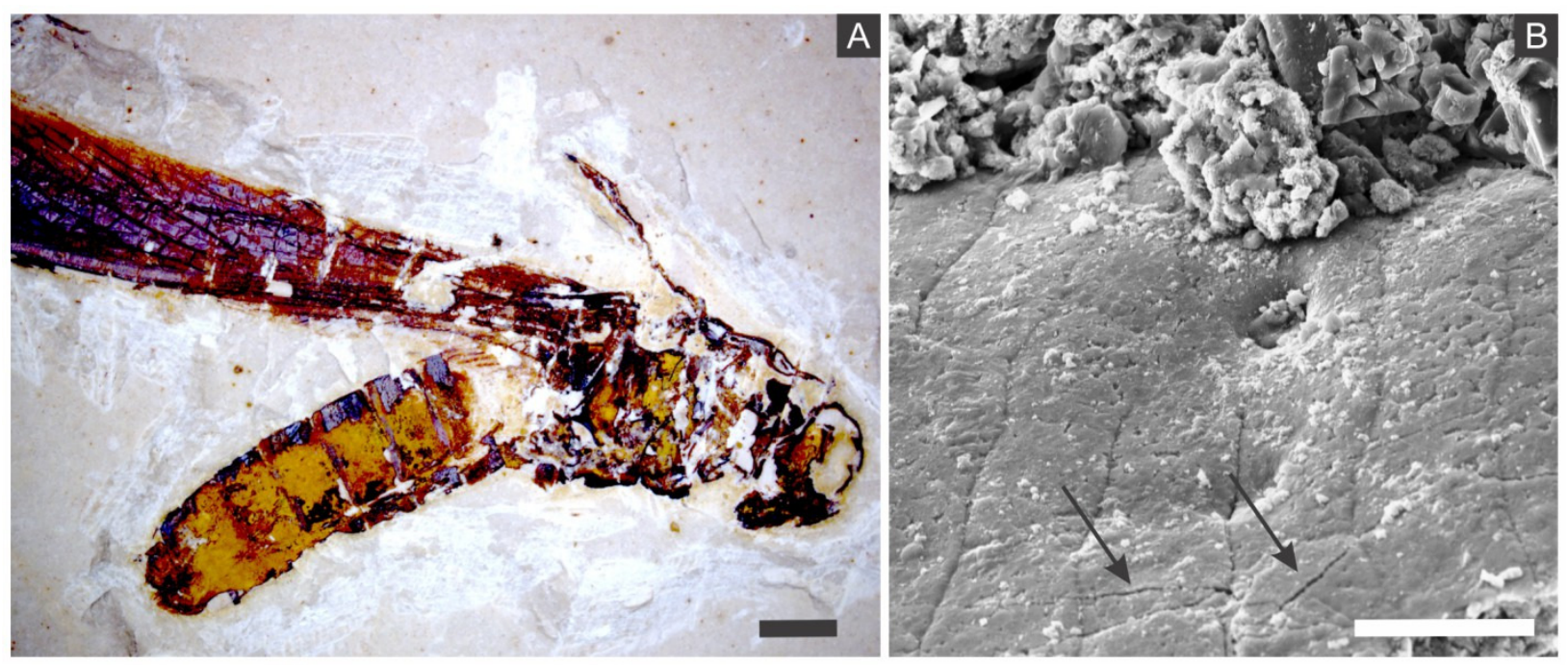

834 Figure 11: Microcracks in the cuticle of a specimen. (A) Orthopteran GP/1E 10368. Scale bar

$835=2 \mathrm{~mm}$. (B) Scanning electron microscopy secondary electron micrograph showing microcracks 836 in the cuticle (arrows). Scale bar $=10 \mu \mathrm{m}$. Beam energy: $10.00 \mathrm{kV}$, spot size: 3.0 , work distance:

$83711.2 \mathrm{~mm}$. 